\title{
Kutbüddîn-i Şîrâzî ve Miftâhu'l-Miftâh adlı eseri
}

\begin{abstract}
APA: Meydan, A. (2019). Kutbüddîn-i Şîrâzî ve Miftâhu'l-Miftâh adlı eseri. RumeliDE Dil ve Edebiyat Araşturmaları Dergisi, (17), 572-595. DOI: 10.29000/rumelide.657944

\section{Öz}

Kutbüddîn-i Şîrâzî, aklî ve nakli ilimlerde döneminin en güçlü isimlerinden biridir. İslâm bilim tarihindeki şöhreti, esas itibariyle birçok disiplinde uzman olup her biri hakkında çok önemli eserler ortaya koymasından kaynaklanmaktadır. Özellikle Şerhu Hikmeti’l-işrâk, Şerhu Külliyyâti’l-Kānûn, Dürretü't-tâc, Nihâyetü'l-idrâk, et-Tuhfetü'ş-Şâhiyye ve Miftâhu'l-Miftâh adlı eserleri, bilim ve düşünce tarihinde çok itibar görmüştür. Şîrâzî’nin, Sekkâkî’nin belagatta zirve kabul edilen eseri Miftâhu'l-'ulûm'a yazdı̆̆ı şerhi Miftâhu'l-Miftâh, uzun yıllar medreselerde okutulan çok sayıda nüshası bulunan kıymetli bir eserdir. Makalemizde önce Kutbüddîn-i Şîrâzînnin hayatı ve eserleri hakkında bilgi verilecek, ardından da bu eser geniş bir şekilde tahlil edilecektir.
\end{abstract}

Ahmet MEYDAN2

Anahtar Kelimeler: Belâgat, Sekkâkî, Miftâhu'l-'ulûm, Kutbüddîn-i Şîrâzî, Miftâhu’l-Miftâh.

\section{Qutb al-Din Shirāzī and his work Miftāh al-Miftāh}

\begin{abstract}
Qutb al-Din Shirāzī is one of the most strongest scholars in his time. His fame in the history of Islamic science is due to his speciality in a lot of diciplines and composing very important boks about them. Especially Sharh al-Hikmat al-Ishrâq, Sharh Kulliyyât al-Qânûn, Durrat al-Taj, Nihayat al-Idrâq, at-Tuhfat al-Shahiyyah and Miftāh al-Miftāh were in demand in the history of science and thought. Miftâh al-Miftâh which he wrote on Miftāh al-Ulūm by Sakkākī was a valuable book that was taught for a long time in madrasas. In our article, we first give information about Shirāzī's life and works, then Miftāh al-Miftāh will be anaylzed in detail.
\end{abstract}

Keywords: Rhetoric, Sakkākī, Miftāh al-Ulūm, Qutb al-Din Shirāzī, Miftāh al-Miftāh.

\section{Giriş}

VII/XIII. yüzyıl, Moğol istilasının getirdiği büyük yıkıma rağmen, İslâm bilim ve düşünce tarihinin en velûd ilim adamlarının yetiştiği dönemlerden biridir. Bu dönemde, din ve dil ilimleri başta olmak üzere, bütün ilimlerde çok yoğun çalışmalar yapılmıştır. Böyle bir dönemde yaşayan Kutbüddîn-i Şîrâzînnin (634-710/1236-1311) eserlerinin önemli bir bölümü "felsefî ilimler", bir kısmı da "felsefî olmayan ilimler" sahasında yer almaktadır.

Bu makale; "Kutbüddîn-i Şîrâzînnin Miftâhu'l-Miftâh Adlı Eserinin Tahkik ve Tahlili (Baştan Müsnedün İleyh Bahsinin Sonuna Kadar)" adlı doktora çalışmamdan elde edilmiştir.

2 Öğr. Gör. Dr., Yalova Üniversitesi, İslami İlimler Fakültesi, Temel İslam Bilimleri, Arap Dili ve BelagatiABD (Yalova, Türkiye), ahmetmeydan@gmail.com, ORCID ID: 00oo-0003-0253-7891 [Makale kayit tarihi: 29.10.2019-kabul tarihi: 20.12.2019; DOI: 10.29000/rumelide.657944] 
Şîrâzî’nin bazı eserleri, bilim ve düşünce tarihinde çok itibar görmüştür. Bunlardan Şerhu Hikmeti'lişrâk, Şerhu Külliyyâti'l-Kānûn, Dürretü’t-tâc, Nihâyetü'l-idrâk, et-Tuhfetü’ş-Şâhiyye ve Miftâhu'lMiftâh en çok önem atfedilen eserleridir.

Abdülkāhir el-Cürcânî̀ye (ö. 471/1078-79) ait Delâilü'l-1̂’câz ve Esrâru'l-belâğa'dan sonra belagat alanında en önemli kabul edilen eser Sekkâkîye (ö. 626/1299) ait Miftâhu'l-'ulûm'dur. Miftâhu'l'ulûm'un, özellikle de meânî ve beyân ilimlerini ele alan üçüncü kısmı üzerine çok fazla çalışma yapılmıştır. ${ }^{3}$ Bu çalışmaların ilk ve en önemlilerinden biri Kutbüddîn-i Şîrâzî (634-710/1236-1311) tarafindan kaleme alınan Miftâhu'l-Miftâh’tır.

Miftâhu'l-Miftâh, birçok belagatçi ve araştırmacı tarafından temel şerhler arasında zikredilmektedir. Mesela Kâtib Çelebi, Miftâhu'l-ulûm'u tanıtırken üç önemli şerhinin olduğunu belirtir. Bunlar; Kutbüddîn-i Şîrâzînnin Miftâhu'l-Miftâh'1, Teftâzânî'nin (ö. 792/1390) Şerhu'l-Miftâh'ı ve Seyyid Şerîf in (ö. 816/1413) el-Misbâh fi Şerhi'l-Miftâh'idır (Çelebi, 1941, II, 1763).

Bu çalışmamızda, önce Kutbüddîn-i Şîrâzî ve eserleri hakında kısa bilgi verilecek, ardından Miftâhu'lMiftâh çeşitli yönleriyle tahlil edilecektir. Ancak eserin hacminin çok fazla olması nedeniyle baştan müsnedün ileyh bahsinin sonuna kadar olan kısmı, çalışmamızın konusu olarak belirledik.

\section{Kutbüddîn-i Şîrâzî’nin hayatı}

Kutbüddîn-i Şîrâzî, Moğol istilasının şehirleri yakıp yıktığı ve ülkeleri harabeye çevirdiği bir dönemde yaşamıştır. Ancak Şîrâzînin hayatının büyük bir bölümünü geçirdiği Şiraz, Sivas ve Tebriz şehirleri, bu felaketten en az etkilenen şehirlerdir (Şîrâzî, nr. 169, vr. 2b.).

Farklı kaynaklar incelendiğinde görülüyor ki; Şîrâzî için birçok künye, lakap ve nisbe kullanılmıştır. Ancak Şîrâzînnin bizzat kendisi, eserlerinde ismini "Mahmûd b. Mes'ûd b. Muslih eş-Şîrâzî" şeklinde kaydetmiştir (Şîrâzî, nr. 169, vr. 1b.). Lakapları arasında ise en yaygın kullanılanları "Kutbüddîn eşŞîrâzî" (Aksarâyî, 2000, s. 107), "el-Allâme" (Birzâlî, t.y., II, 487)4, "eş-Şârih el-Allâme" (İbn Hacer 1931, IV, 339).) ve "el-Allâme eş-Şirâzî” (Safedî, 1999, V, 409) şeklindedir.

Kutbüddîn-i Şîrâzî, kaynakların çoğuna ve tercih edilen görüşe göre 634/1236 yılında Şîrâz'da doğmuştur. 5

Küçük yaşta eğitim hayatına başlayan Şîrâzî, ilk eğitimini doğduğu yer olan Şirâz'da babası Ziyâüddin Mes'ûd ile amcası Kemâlüddîn Ebü'l-Hayr'dan aldı (Şînâzî, nr. 3467, vr. 1b.). Bunların yanı sıra Şemsüddîn el-Kîş̂̂́6 (ö. 695/1295) ve Şerefüddîn Zekî el-Bûşekânî7 (ö. 680/1281-82) adlı iki önemli hocadan ders aldı (Şîrâzî, nr. 3467, vr. 1b.).

3 Miftâh üzerine yapılan çalışmalar hakkında bilgi için bkz. Alak, 2011a, s. 61-95

4 Mutavvel Şarihi Musannifek ve Şevkâni başta olmak üzere birçok alim, "Allâme” lakabı mutlak kullanıldığında Şîrâzînnin kastedildiğini ifade etmişlerdir. Musannifek, Teftâzânî’nin eserlerinde "Allâme” ifadesini kayıtsız olarak kullandığında Şîrâzî̀yi kastettiğini belirtmektedir. Ancak Şevkânî, vakıa böyle olsa da "Allâme” vasfına layık olan birçok kimse olmasına rağmen bunun sadece Şî̂âzî için kullanılmasını eleştirmektedir. Musannifek, Hâşiye ale'l-Mutavvel, Konya Yusufağa Ktp, nr. 3467, s. 25 (Bu yazma sayfa numarası ile numaralandırılmış.); Şevkânî, t.y., s. 300.

5 Ayrıntıll bilgi için bkz. Zehebî, t.y., s. 116; Safedî, 1999, XV, 200-201; Sübkî, 1964, X, 386; İbn Hacer, 1931, IV, 339; Wiedemann, 1977, VI, 1049-1051.

Hakkında bilgi için bkz. Zehebî, t.y., s. 113; Cüneyd-i Şîrâzî, 1965, s. 110-113, Mînovî, 1969, s. 166.

Hakkında bilgi için bkz. Cüneyd-i Şîrâzî: 1965, s. 298; Mînovî, 1969, s. 167. 
Şîrâzî, Şiraz'dan ayrıldıktan sonra dönemin en önemli ilmî merkezi olarak kabul edilen Merâga Rasathanesi'nde 658-667 (1259-1269) yılları arasında Nasîruddîn et-Tûsî, Necmüddîn el-Kâtibî (ö. 675/1277), Müeyyidüddîn el-Urzî (ö. 664/1265-1266) başta olmak üzere birçok önemli ilim adamından ders aldı (Şîrâzî, nr. 3467, vr. 2b; Razavî, 1991, s. 46.).

Naklî ilimlere biraz daha ağırlık vermesi gerektiğini düşünen Şîrâzî, Kazvin'e giderek 668-671 (12691272) yılları arasında Alâüddîn Muhammed b. Ebî Bekr et-Tâvûsî el-Kazvînî'den fikıh ve belağat dersleri aldı (Zehebî, t.y., s. 113).

671/1272 yılında Horasan'dan Bağdat'a seyahat eden ve burada bir yıl civarı Nizâmiye Medresesinde araştırmalar yapan Şîrâzî, ardından Konya'ya hareket etti (Şîrâzî, nr. 3467, vr. 2b.). Burada kaldığı süre zarfinda Mevlânâ Celâleddîn-i Rûmî̀nin sohbetlerine katıldı. ${ }^{8}$ Özellikle Sadreddîn Konevînin hankâhında verdiği hadis derslerine devam edip 673/1274 yllında bu büyük âlimden hadis icâzeti aldı. ${ }^{9}$

Kutbüddîn-i Şîrâzî ilim tahsili yaparken bir yandan da çok kıymetli öğrenciler yetiştirmiştir. Bu öğrencileri vasıtasıyla Şîrâzînnin ilim çevrelerine çok büyük etkisi olmuştur. Kemâleddin el-Fârisî (ö. 718/1319), İbnü’l-Fuvatî (ö. 723/1323), Adudüddîn el-Îcî (ö. 756/1355) ve Kutbüddin er-Râzî (ö. 766/1365) bunlardan bazllarıdır.

Döneminin önemli şahsiyetlerinden olan Şîrâzî, Anadolu Selçuklu ve İlhanlı devletleri nezdinde de çok saygın bir ilim adamı idi. Bu nedenle devlet adamları tarafından kendisine çok önemli görevler tevdi edilmiştir (Şîrâzî, nr. 3467, vr. 1b.). Bimâristân-1 Muzafferîde ve Gevher Nesibe Dâruşşifâ’sında hekimlik; Pervâne Bey Medresesinde, Sivas Gökmedresede ve Şenb-i Gâzân Rasathanesi'nde müderrislik; Anadolu'da başkadılık ve İlhanlılar ile Memlükler arasında elçilik bu görevlerden bazılarıdır.

Şîrâzî, kaynakların çoğunluğuna göre 710 yılı Ramazan ayında (Şubat 1311) Tebriz'de vefat etti.10

\section{Kutbüddîn-i Şîrâzî’nin eserleri}

Kutbüddîn-i Şîrâzînin eserlerinin önemli bir bölümü felsefî ilimler, bir kısmı da felsefî olmayan ilimler sahasında yer almaktadır. Felsefi ilimlerden metafizik, geometri, astronomi ve tıp alanında, felsefi olmayan ilimlerden ise tefsir, usûl-i fikıh ve belâgat alanında çok kıymetli eserler kaleme almıştır. Bu ilim sahalarında şerh, hâşiye ve risâleleri olduğu gibi, müstakil kitap çalışmaları da bulunmaktadır. Söz konusu eserlerini Arapça ve Farsça olarak telif etmiştir. Bu eserlerin büyük bir kısmı günümüze kadar ulaşmış olmakla birlikte, çok az sayıda eseri basılmıştır.

\subsection{Felsefí/hikemî ilimler ile ilgili eserleri}

Şîrâzî, akli ve nakli ilimlerde otorite olduğu için Allâme lakabiyla meşhur olmuş bir âlimdi. (Birzâlî, t.y., II, 487; Zehebî, t.y., s. 116). Felsefî ilimler alanında çok kıymetli eserler kaleme alması nedeniyle Şîrâzînin, İslâm bilim tarihinde önemli bir yeri vardır. Onun metafizik, geometri, astronomi ve tıp alanlarında kaleme aldığı eserleri vardır.

Mevlânâ ile ilişkileri hakkında bkz. Eflâkî, Ahmed (1986). s. 184, 346.

İcâzetin aslı için bkz. İbnü’l-Esîr, Câmiu’l-usûl, Millet Kütüphanesi, Feyzullah Efendi Blm., nr. 30o, vr. 1a.

Bkz. İbnü’l-Fuvatî, 1962, III, 441; Zehebî, t.y., s. 115; Sübkî, 1964, X, 386; Şevkânî, t.y., II, 299; Walbridge, 1983, s. 34-35; Şerbetçi, 2002, XXVI, 487; Keleş, 2008, s. 73-75. 
Tespit edebildiğimiz kadarıyla Şîrâzînin metafizik alanında yazdığı eserlerden kendisine aidiyeti kesin olanlar dokuz tanedir. Bunlar; Şerhu Hikmeti'l-İşrâk, Dürretü't-tâc li-ğurreti'd-Dîbâc, Kitâbü’l-fevâid fì şerhi Hikmeti 'ayni'l-kavâìd, Şerh alâ Kitâbi Ravdati’n-nâzır, Cevâb an es'iletin evradehâ 'İmâdüddîn el-Kâşî ale'l-Kavâidi'l-hikemiyye, Şerhu'l-işârât, Risâle fi isbâti’l-vâcib, Risâle fi Tahkîki'lcebr ve'l-kader ve Risâle fi'l-hikme'dir. (Meydan, 2019, s. 96-108)

Geometri alanında yazdığı dört eseri vardır. Bunlar; Tercüme-i Tahrîr-i usûl-i Öklides, Risâle der Tevhîd-i kazâyâ-yı Öklides, Tahrîr-i Öklides ve Risâle fí hareketi'd-dahrece ve'n-nisbe beyne'l-müstevi ve'l-münhanîdir. (Meydan, 2019, s. 108-111)

Şîrâzînnin astronomi alanında yedi eseri vardır. Bunlar; Nihâyetü'l-İdrâk fi Dirâyeti’l-Eflâk, Risale Müteallika bi Ba'zı İltibasi Nihâyeti'l-İdrâk, et-Tuhfetü'ş-Şâhiyye fi'l-Hey'e, İhtiyârât-ı Muzafferî, Fe'altü Felâ Telüm fi'l-Hey'e, Muhtasar der İlm-i Hey'ât ve Risâle-i Muğniye'dir. (Meydan, 2019, s. 111125)

Bunların dışında Şîrâzî, en önemli ve uzun süreli çalışmalarını tıp alanında yapmıştır. Bu alanda dört eser kaleme almıştır. Bunlar; Şerhu Külliyyâti'l-Kānûn, Risâle fi Beyân'il-hâce ile’t-tıb ve âdâbi'l-etıbbâ ve vasâyâhüm, Risâle fi'l-Baras ve Risâle fi'n-Nâri'l-Fârisî'dir. (Meydan, 2019, s. 125-133)

\subsection{Felsefî olmayan/gayri hikemî ilimler}

Ağırlıklı olarak felsefî ilimler ile meşgul olup eserler veren Şîrâzî, tesbit edebildiğimiz kadarıyla naklî ilimler ile ilgili tefsir, fikıh ve belâgat alanlarında eserler yazmıştır.

Tefsir alanındaki tek çalışması Fethu'l-Mennân fì Tefsîri'l-Kurân adlı hacimli eseridir (Ertuğrul, 2011, s. 85-86). Fıkıh usûlü ile ilgili çalışması, İbnü'l-Hâcib'in Muhtasarü'l-Müntehâ isimli eserine yazmış olduğu Şerhu Muhtasari'l-Müntehâ adlı şerhtir (Zehebî, t.y., s. 114; Safedî, 1999, XV, 201.). Dil ile ilgili çalışması ise Sekkâkî’nin Miftâhu'l-‘ulûm'una yazmış olduğu Miftâhu'l-Miftâh adlı şerhtir.

Nakli ilimler alanında Şîrâzî̀ye ait olan bir başka eser daha vardır. Bu da, Gazzâlî̀nin İhyâ’'sından seçmeler yaparak oluşturduğu İntihâb-ı Süleymanî adlı farsça eseridir (Mînovî, 1969, s. 203-204).

\section{Miftâhu'l-Miftâh'ın tahlili}

Bu başlık altında önce Miftâhu'l-Miftâh'ın Kutbüddîn-i Şîrâzîye aidiyyeti, başı ve sonu, yazılış tarihi ve yeri, yazılma nedeni ve süreci, muhtevası ve önemi ile ilgili bilgiler verilecektir. Ardından bu şerhte yararlanılan kaynaklar, şerhin kütüphanelerdeki nüshaları ve Şîrâzînnin şerh yöntemi açılanacaktır.

\subsection{Eserin adı}

Bu eser için kaynaklarda ve kütüphane kayıtlarında birkaç farklı isimlendirme olsa da en yaygın olan Miftâhu'l-Miftâh ismidir. Çünkü Şîrâzî, şerhin mukaddimesinde eseri bu isimle adlandırmış ve şöyle demiştir: “Bu, Miftâh’ın Miftâhu’l-Miftâh adlı şerhidir.” (Şîrâzî, nr. 169, vr. 5a).

\section{2. Şîrâzî̀ye âidiyeti}

Şîâyî, şerhin Miftâhu'l-Miftâh'ın mukaddimesinde ismini açıkça yazarak eserin kendine ait olduğunu belirtmiştir. Şîrâzî, şu ifadeleri kullanmaktadır: “... Allah’ın yarattıkları arasında ona en çok muhtaç 
olan Mahmud b. Mesud b. el-Muslih eş-Şîrâzî, der ki: ..... Bu, Miftâh'mn Miftâhu'l-Miftâh adlı şerhidir...” (vr. 1b, 5a).

Ayrıca ilk kaynaklardan itibaren biyografik / bibliyografik kaynaklarda ${ }^{11}$ ve kütüphanelerdeki tüm nüshaların kayıtlarında eserin Şîrâzîye nispet edildiği görülmektedir.

\subsection{Başı ve sonu}

Miftâhu'l-Miftâh'ın kütüphanelerde pekçok nüshası bulunmaktadır. Araştırmacıların bu nüshalara kolay ulaşması ve başka eserlerle karıştırmaması için eserin başından ve sonundan bir bölümü burada aktaracağız.

\subsubsection{Baş tarafi}

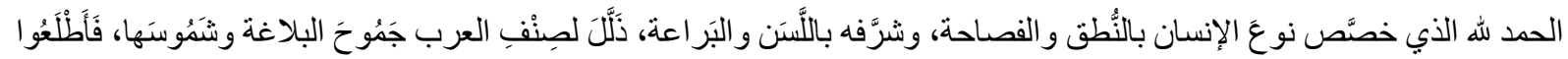

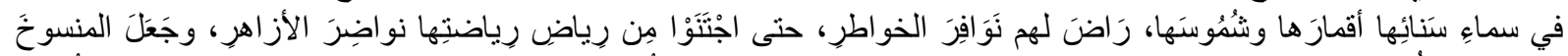

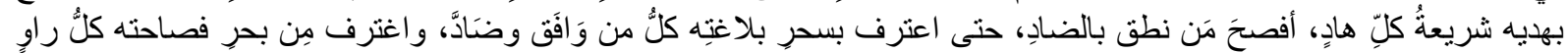

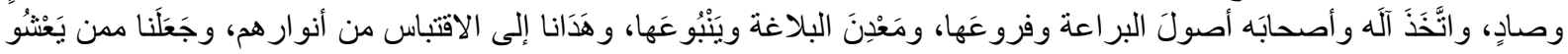

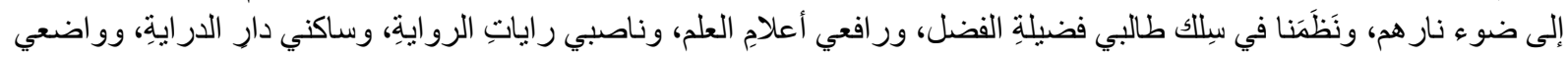

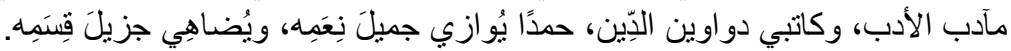

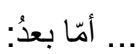

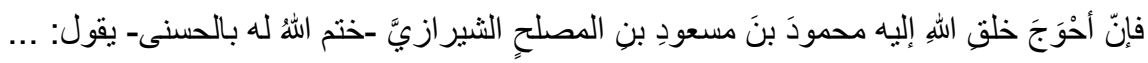

\subsubsection{Son tarafi}

$$
\begin{aligned}
& \text { وهذا، ونحن نعود في الئختتم إلى ما بدأنا به في المُفتتح، ونقول: } \\
& \text { الله أحمدُ حمدَ عبدٍ واضعِ خدَّ الخشوع على الثَّرى تعظيما }
\end{aligned}
$$

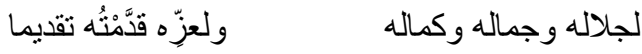

$$
\begin{aligned}
& \text { صلى الإله على ابن آمنةً الذي جاءت به سبطَ البنان كريما } \\
& \text { با أيُّها الر اجون منه شفاعةً }
\end{aligned}
$$

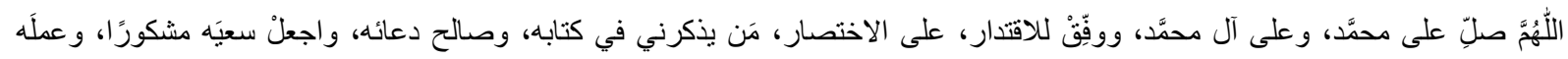

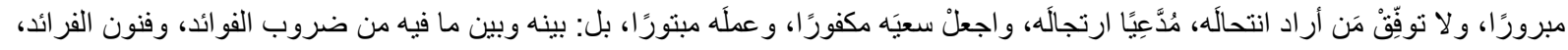

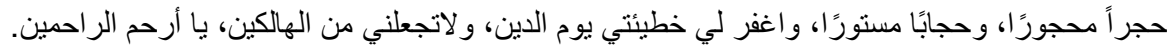

\subsection{Yazılış tarihi ve yeri}

Kutbüddîn-i Şîrâzînin Miftâhu'l-Miftâh’ı ne zaman yazdığına dair eserde açık bir bilgi bulamadık. Ancak Şîrâzî, bu eseri Tebriz'de yazdığını belirtmektedir (vr. 2b). 690/1290 yılından sonra Tebriz’e yerleşen Şîrâzî, özellikle belâgat alanında önemli çalışmalar yapmış (vr. 2a) ve bu alanda Sekkâkî’nin Miftâhu'l-ulûm adlı eserini okutup icâzet vermişti. Verdiği bu icâzette 21-29 Zilhicce 699 (7-15 Eylül

${ }_{11}$ Bkz. Safedî, 1999, XV, 201; Sübkî, 1964, X, 386; İbn Hacer, 1931, IV, 340; Çelebi, 1941, II, 1763; Şevkânî, t.y., s. 299; Ziriklî, 1951, VII, 188; Mînovî, 1969, s. 174. 
1300) tarihini not düşmüştür. ${ }^{12} \mathrm{Bu}$ eseri okuturken aldığı notları genişleterek daha sonra Miftâhu'lMiftâh'ı yazmıştı. Öyleyse bu eser bu tarihten sonra yazılmış olmalıdır. Muhtemelen o sırada yazım süreci devam ediyordu.

Diğer taraftan Şîrâzînin önemli gördüğü bir kişiye hediye etmek için istinsah ettirdiği ve hatimesini de bizzat kendisinin kontrol edip kendi el yazısıyla not düştüğü (vr. 356a) Miftâhu'l-Miftâh'ın Süleymaniye Ktp., Beşirağa (Eyüp) Blm., nr. 169'daki nüshasının zahriyesine Receb 702 (Şubat-Mart 1303) tarihi düşülmüş̧ür. Bu durumda eser bu tarihten önce yazılmış olmalıdır. Ayrıca Şîrâzînin Necmüddîn Muhammed et-Tebrîzîye verdiği Zilhicce 701 (Temmuz-Ağustos 1302) tarihli Miftâhu'l-Miftâh icâzeti bu ihtimali güçlendirmektedir. ${ }^{13}$

Bu bilgiler ışığında eserin 700 (1300-1301) veya 701 (1301-1302) yılında yazılmış olduğu söylenebilir. Ancak Miftâhu'l-Miftâh'ın bazı nüshalarının ferağ kaydında bu eserin telifinin Evâhir-i (21-30) Receb 701 (22-31 Mart 1302) tarihinde tamamlandığı kaydı yer almaktadır. ${ }^{14}$ Dolayısıyla bu kayıtlar, eserin 701 (1302) yllında telif edildiği ihtimalini güçlendirmektedir.

\subsection{Muhtevâsı}

Kutbüddîn-i Şîrâzî tarafından yazılan Miftâhu'l-Miftâh, Sekkâkî̀ye ait olan Miftâhu'l-ulûm'un şerhidir. Dolayisıyla Miftâhu'l-Miftâh'n muhtevâsı, Şîrâzî'nin mukaddimesi hâriç tutulursa, Miftâhu'l-'ulûm'un muhtevâsından ayrı düşünülemez. Ancak tahlil ettiğimiz bölüm, Müsnedün ileyhin sonuna kadar olduğu için Miftâhu'l-Miftâh'ın muhtevası bu bölümle sınırlandırılacak ve tez planı şeklinde verilecektir.15 Ayrıca bu planın varak numaralandırılması için Süleymaniye Ktp., Beşir Ağa (Eyüp) Blm., nr. 169 esas alınacaktır.

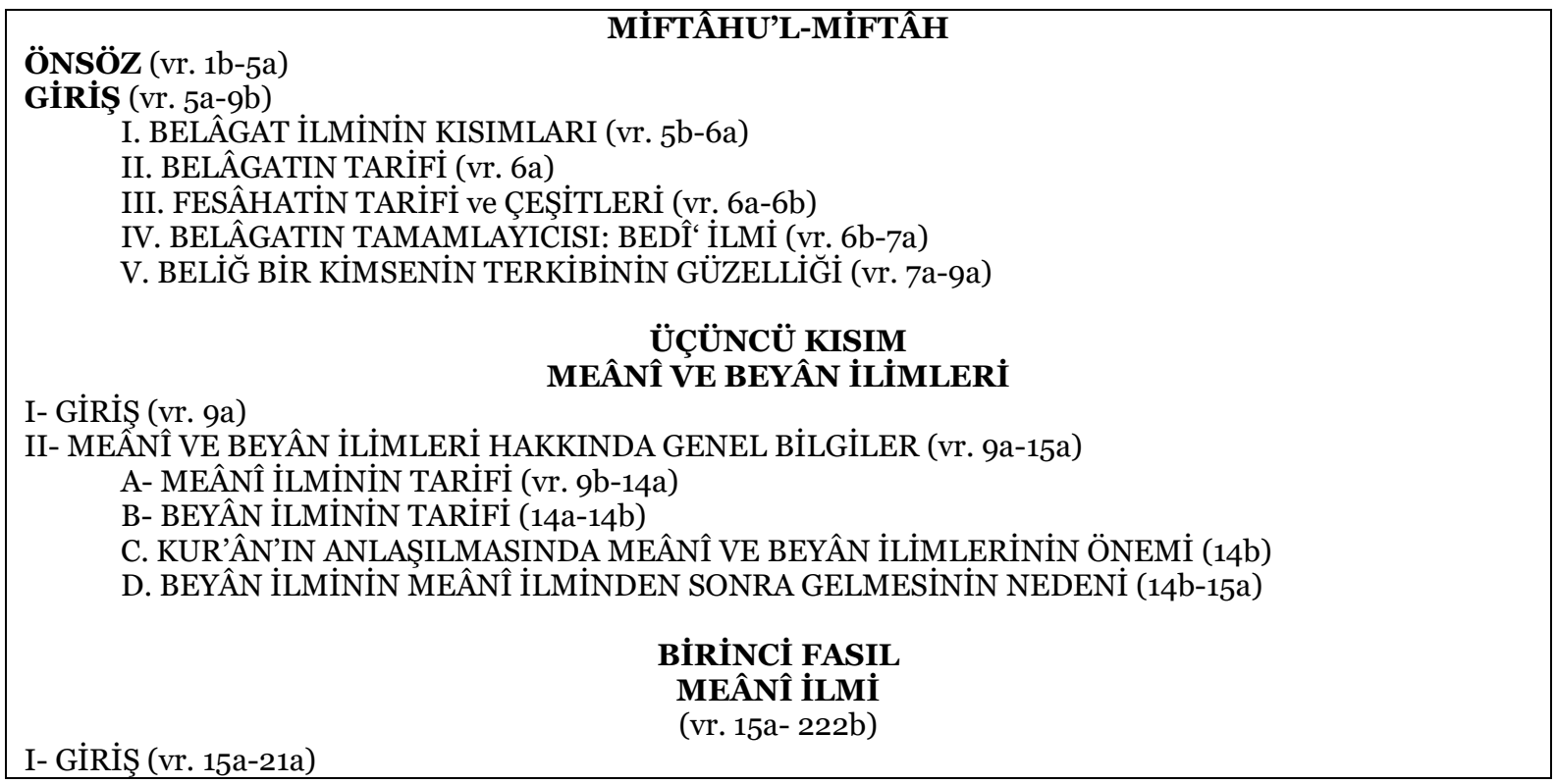

12 İcâzet örneği için bkz. Sekkâkî, Miftâhu’l-Ulûm, Râgıp Paşa, nr. 1282, zahriye.

13 Tam adı Necmüddîn Ebû Bekr Muhammed b. Muhammed et-Tebrîzî́dir. Necmüddîn Ebû Bekr et-Tebrîzî, 701 yılı Zilhicce ayında (Temmuz-Ağustos 1302) Kutbüddîn-i Şîrâzî'den icâzet almıștır.

Arapça metin ve içerik için bkz. Kutbüddîn-i Şîrâzî, Miftâhu'l-Miftâh, İran Milli Ktp., nr. 2839 (1191), (ferağ kaydından sonra sonuna ekli).

14 Bu kayıtlar için bkz. Süleymaniye Ktp., Bağdatlı Vehbi Blm., nr. 1775, vr. 233a; Süleymaniye Ktp., Serez, nr. 2476, vr. 436a; Atıf Efendi Ktp., nr. 2372, vr. 287b; Süleymaniye Ktp., Fatih Blm., nr. 4666, vr. 177b.

15 Tez planı oluşturulurken sistem olarak şu eserden istifade edilmiştir: Alak, 2011a, s. 107-108. 


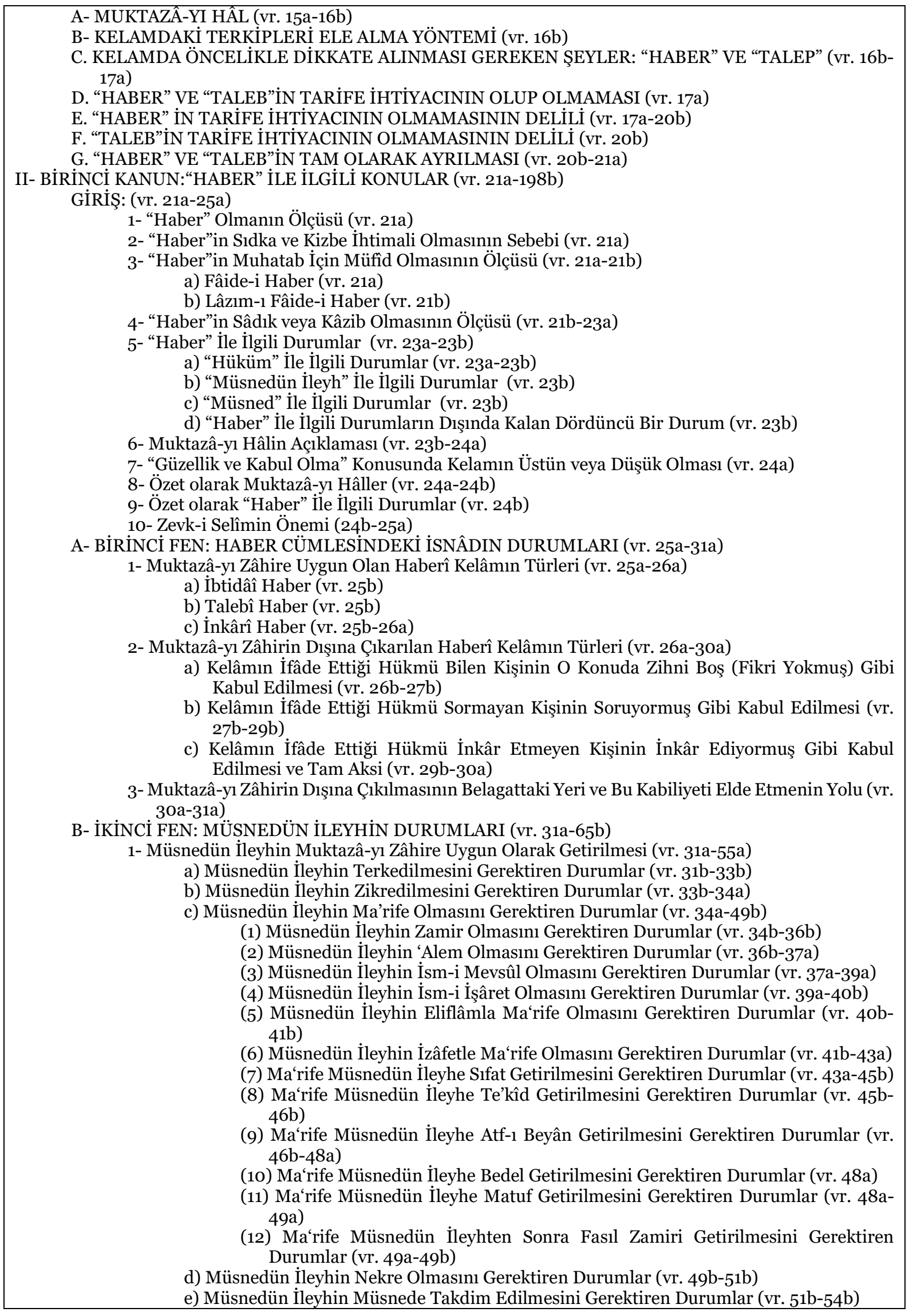




\begin{tabular}{|l}
\hline f) Müsnedün İleyhin Müsnedden Sonraya Bırakılmasını Gerektiren Durumlar (vr. 54b) \\
g) Nekre Olan Müsnedün İleyhin Tahsis Edilip Edilmemesini Gerektiren Durumlar (vr. \\
54b-55a) \\
h) Müsnedün İleyhin Müsnede Kasr Edilmesini Gerektiren Durumlar (vr. 55a) \\
2- Müsnedün İleyhin Muktazâ-yı Zâhirin Dışına Çıarılması (vr. 55a-63b) \\
a) Müsnedün İleyhin Zamir Yerine İsm-i İşâret Olarak Getirilmesi (vr. 55b-56a) \\
b) Müsnedün İleyhin İsm-i Zâhir Yerine Zamir Olarak Getirilmesi (vr. 56a-56b) \\
c) Müsnedün İleyhin Zamir Yerine İsm-i Zâhir Olarak Getirilmesi (vr. 56b-57a) \\
d) Müsnedün İleyhin Mütekellim Zamiri Yerine İsm-i Zâhir Olarak Getirilmesi (vr. 57a- \\
57b) \\
e) İltifât Sanatı (vr. 57b-6ob) \\
(1) Bazı İltifat Yerlerinde İltifatın İçerdiği Manaların İncelikleri (vr. 6ob) \\
(2) Fatihâ Suresindeki İltifatın İçerdiği Manaların İncelikleri (vr. 6ob-62a) \\
(3) İmruülkays'ın Beyitlerindeki İltifatın İçerdiği Manaların İncelikleri (vr. 62a- \\
63b) \\
3- İkinci Fennin Sonu (vr. 63b-65b)
\end{tabular}

\section{6. Önemi}

Abdülkāhir el-Cürcânî’nin telifi olan Delâilü'l-î‘câz ve Esrâru'l-belâğa'dan sonra belâgat alanında en önemli kabul edilen eser, Sekkâkî̀nin Miftâhu'l-'ulûm adlı eserinin belâgate dair olan üçüncü kısmıdır. Bu eserin ilk şerhlerinden biri olan Miftâhu'l-Miftâh, tam ve memzûc (metin ve şerh iç içe) olması itibarıyla ön plana çıkmaktadır. Ayrıca Miftâhu'l-ulûm'da belâgat kavramlarının yanı sıra mantık kavramlarının da kullanıldığı bilinmektedir. Bu nedenle dönemin felsefe ve mantık alanında otorite ismi olan Kutbüddîn-i Şîrâzî tarafından yazılmış olması da bu şerhin ayrı bir özelliğidir.

Miftâhu'l-Miftâh, birçok belâgatçi ve araştırmacı tarafından temel şerhler arasında zikredilmektedir. Mesela Kâtib Çelebî, Miftâhu'l-ulûm üzerine yapılan çalışmaları anlatırken üç önemli şerhinin olduğunu belirtir. Bunlar; Kutbüddîn-i Şîrâzînin Miftâhu'l-Miftâh', Teftâzânî'nin Şerhu'l-Miftâh'ı ve Seyyid Şerîf el-Cürcânî'nin el-Misbâh fi Şerhi'l-Miftâh’idır (Çelebi, 1941, II, 1763).

\subsection{Yararlandığı kaynaklar}

Şîrâzî, Miftâhu’l-Miftâh'in tahlil ettiğimiz bölümünde tespit edebildiğimiz kadarılya otuz üç adet kaynak kullanır. Bunlardan üç tanesi tefsir ve ulûmü'l-Kur'ân, bir tanesi garîbü'l-hadîs, bir tanesi usûl-i fikıh, bir tanesi tasavvuf ve ahlâk, dört tanesi mantık ve felsefe, dört tanesi lügat ve emsâl, altı tanesi sarf ve nahiv, beş tanesi belâgat ve sekiz tanesi de edebiyat, şiir ve şiir şerhleri ile ilgili kitaplardır.

Cevherî̀nin es-Sihâh'1, Merzûkî’nin Şerhu Dîvâni'l-hamâse'si, Abdülkāhir el-Cürcânî’nin Delâilu'li’câz'ı, Hatîb et-Tebrîzînin Şerhu İhtiyârâtil-Mufaddal'i ve Zemahşerî̀nin el-Keşşâf 1 en çok yararlandığı eserler olarak öne çıkmaktadır.

Şîrâzînin yararlandığı tüm kaynakları önce konularına göre tasnif edecek, sonra da her birini kendi içinde yazarlarının vefat tarihlerine göre kronolojik olarak sıralayacağız: ${ }^{16}$

\section{Tefsir ve Ulûmu'l-Kur'ân kitapları}

Câhiz: Ebû Osmân Amr b. Bahr b. Mahbûb el-Câhiz el-Kinânî (ö. 255/869).

\footnotetext{
16 Şîrâzînin Miftâhu'l-Miftâh'ta yararlandığı kaynaklarını incelerken sistem olarak şu eserden istifade edilmiştir: Alak,
} 2011b, VI, Sayl 2, 109-126. 


\section{(1) Nazmü'l-Kur'ân}

Şîrâzî, bir yerde kaynak olarak kullandığı bu eserin müellifini "el-Câhiz"; eseri ise "Nazmü’l-Kur'ân" adıyla zikretmektedir (vr. 2b).

Zemahşerî: Cârullâh Ebü’l-Kāsım Mahmûd b. Ömer el-Hârizmî ez-Zemahşerî (ö. 538/1144).

\section{(2) el-Keşşâf an hakāiki ğavâmızı't-Tenzîl ve 'uyûni'l-ekāvîl fî̀ vücûhi't-te’vîl}

Şîrâzînnin en çok etkisinde kaldığı eserlerden biri olan bu kaynaktan altı yerde yararlandığ görülmektedir. Eserin müellifini "Sâhibü’l-Keşşâf", "ez-Zemahşerî", "Cârullâh" ve "Cârullâh elAllâme” adlarıyla; eseri ise "el-Keşşâf” adıyla zikretmektedir (vr. 2b, 41a, 46b, 47b, 56b, 57b).

Kevâşî: Ebü’l-Abbâs Muvaffakuddîn Ahmed b. Yûsuf b. el-Hasen el-Kevâşî el-Mevsılî (ö. 680/1281).

\section{(3) Tefsîru'l-Kevâşî}

Şîrâzî, iki yerde kaynak olarak kullandığı bu eserin müellifini "el-Kevâşı”" adıyla zikretmiş ancak eserin adını zikretmemiştir (vr. 27a, 47b).

\section{Garîbü'l-Hadis kitabı}

Zemahşerî: Cârullâh Ebü'l-Kāsım Mahmûd b. Ömer el-Hârizmî ez-Zemahşerî.

\section{(4) el-Fâik fî garîbi'l-hadîs ve'l-eser}

Şirâzî, bir yerde kaynak olarak kullandığı bu eserin müellifini “Cârullâh” adıyla zikretmiş ancak eserin adını zikretmemiştir (vr. 55b).

\section{Fıkıh ve Usûl-i Fıkıh kitapları}

Ebü’l-Hüseyn el-Basrî: Ebü’l-Hüseyn Muhammed b. Alî b. Tayyib el-Basrî (ö. 436/1044).

\section{(5) el-Mu'temed fî usûli'l-fikh}

Şîrâzî, bu eseri üç yerde kaynak olarak kullanmaktadır. Eserin müellifini “Ebü'l-Hüseyn” ve "Ebü’lHüseyn el-Basrî” adlarıyla zikretmiş ancak eserin adını zikretmemiş̧tir (vr. 18a, 18b, 45a).

\section{Tasavvuf ve ahlâk kitabı}

Râgıb el-İsfahânî: Ebü’l-Kâsım Hüseyn b. Muhammed b. el-Mufaddal er-Râgıb el-İsfahânî (ö. V/XI. yüzyılın ilk yarısı).

\section{(6) ez-Zerî‘a ilâ mekârimi’ş-Şerî‘a}

Şîrâzî, bir yerde kaynak olarak kullandığı bu eserin müellifini “Ebü’l-Kāsım er-Râgıb” adıyla; eseri ise "ez-Zerî‘a fî̀ mekârimi’ş-şerî‘a” adlarıyla zikretmektedir (vr. 7a).

\section{Mantık ve felsefe kitapları}

İbn Sina: eş-Şeyh er-Reîs Ebû Alî el-Hüseyn b. Abdillâh b. Alî b. Sînâ (ö. 428/1037).

\section{(7) eş-Şifâ}

Şirâzî, bu eseri üç yerde kaynak olarak kullanmaktadır. Eserin müellifini "eş-Şeyh"; eseri ise "eş-Şifâ" adiyla zikretmektedir (vr. 9a, 13a, 13b, 19a, 3ob).

\section{(8) el-İşârât ve't-tenbîhât}

Şîrâzî, bu eseri aynı varakta iki yerde kaynak olarak kullanmaktadır. Eseri "el-İşârât" adıyla zikretmektedir. Müelifi ise zikretmemektedir (vr. 19a). 
Fahreddin er-Râzî: Ebû Abdillâh (Ebü'l-Fazl) Fahruddîn Muhammed b. Ömer b. Hüseyn er-Râzî (ö. 606/1210).

\section{(9) Şerhu'l-İşârât ve't-tenbîhât}

Şirâzî, bu eseri bir yerde kaynak olarak kullanmaktadır. Eserin ve müellifin adını zikretmemektedir (vr. 19a).

Nasîrüddîn Tûsî: Ebû Ca'fer Nasîrüddîn Muhammed b. Muhammed b. el-Hasen et-Tûsî (ö. 672/1274).

\section{(10) Şerhu'l-İşârât (Hallü müşkilâti'l-İşârât)}

Şîââi, bu eseri iki yerde kaynak olarak kullanmaktadır. Eserin müellifini "el-Üstâz el-Muhakkık" ve "eş-Şârih el-Allâme" adlarıyla; eseri ise "Şerhu'l-İşââat" adıyla zikretmektedir (vr. 13a, 19a).

\section{Lügat kitapları}

İmâm Halîl: Ebû Abdirrahmân el-Halîl b. Ahmed el-Ferâhîdî (ö. 175/791).

\section{(11) Kitâbü'l-‘Ayn}

Şirâzî, bir yerde kaynak olarak kullandığı bu eserin müellifini "el-Halîl”; eseri ise "el-'Ayn" adıyla zikretmektedir (vr. 42a).

Asmaî: Ebû Saîd Abdülmelik b. Kureyb el-Asmaî el-Bâhilî (ö. 216/831)

\section{(12) Halku'l-insân}

Şirâzî, bu eseri bir yerde kaynak olarak kullanmaktadır. Müellifi "el-Asmaî" adıyla zikretmiş ancak eserin adını zikretmemiştir (vr. 42a).

İbnü’s-Sikkît: Ebû Yûsuf Ya'kûb b. İshâk es-Sikkît (ö. 244/858).

\section{(13) Islâhu'l-mantık}

Şîrâzî, dört yerde kaynak olarak kullandığı bu eserin müellifini “ỉbnü’s-Sikkît” adıyla zikretmektedir. Eserin adını ise zikretmemektedir (vr. 30b, 35a, 35b, 56a).

Cevherî: Ebû Nasr İsmâ‘̂̂l b. Hammâd el-Cevherî (ö. 400/10og'dan önce).

\section{(14) Tâcü'l-lüğa ve sıhâhu'l-‘Arabiyye (Sıhâhu'l-lüğa)}

Ş̂râzînin en çok kullandığı eserlerden biri olan bu kaynaktan on beş yerde isim vererek yararlandığı görülmektedir. Eserin müellifini "el-Cevherî"; eseri ise "es-Sihâh" adıyla zikretmektedir (vr. 17a, 23b, 24b, 25a, 30a, vd.).

Şirâzî, garib kelimelerin açıklamasında sıkça başvurduğu bu eseri kaynak aldığını çoğunlukla belirtmemektedir.

\section{Nahiv kitapları}

Sîbeveyhi: Ebû Bişr (Ebû Osmân, Ebü’l-Hasen, Ebü'l-Hüseyn) Sîbeveyhi Amr b. Osmân b. Kanber elHârisî (ö. 180/796).

\section{(15) el-Kitâb}

Şirâzî, üç yerde kaynak olarak kullandığı bu eserin müellifini "Sîbeveyhi” adıyla zikretmektedir. Eserin adını zikretmemiştir (vr. 19a, 48a, 59a). 
Zemahşerî: Cârullâh Ebü'l-Kāsım Mahmûd b. Ömer el-Hârizmî ez-Zemahşerî.

\section{(16) el-Mufassal fi 'ilmi'l-'Arabiyye}

Şirâzî, bir yerde kaynak olarak kullandığı bu eserin müellifini “Sâhibü’l-Keşşâf” adıyla zikretmektedir. Eserin adını ise zikretmemiştir (vr. 46b).

İbnü’l-Hâcib: Ebû Amr Cemâlüddîn Osmân b. Ömer b. Ebî Bekr (ö. 646/1249).

\section{(17) el-Kâfiye}

Şirâzî, iki yerde kaynak olarak kullandığı bu eserin müellifini “ỉbnü’l-Hâcib” adıyla zikretmektedir. Eserin adını zikretmemiştir (vr. 1ob, 48b).

\section{(18) Şerhu'l-Kâfiye}

Şîrâzî, bu eseri iki yerde kaynak olarak kullanmaktadır. Eserin adını zikretmemiştir (vr. 1ob, 48b).

\section{(19) Şerhu'l-Vâfiye fî nazmi'l-Kâfiye}

Ş̂râzî, bu eseri üç yerde kaynak olarak kullanmaktadır. Eserin müellifini “ỉbnü’l-Hâcib” adıyla; eseri ise "Şerhu'l-Vâfiye" adıyla zikretmektedir (vr. 46b, 48b).

İbn Mâlik: Ebû Abdillâh Cemâlüddîn Muhammed b. Abdillâh b. Mâlik et-Tâi el-Endelüsî el-Ceyyânî (ö. 672/1274).

\section{(20) Şerhu Teshîli'l-Fevâid}

Şirâzî, bu eseri iki yerde kaynak olarak kullanmaktadır. Eserin müellifini “i̇bnü’l-Mâlik” adıyla, eseri ise "Şerhu Teshîli'l-fevâid ve "et-Teshîl" adıyla zikretmektedir (vr. 11a, 27a).

\section{Belâgat kitapları}

Abdülkāhir el-Cürcânî: eş-Şeyh el-İmâm Ebû Bekr Abdülkāhir b. Abdirrahmân el-Cürcânî en-Nahvî (ö. 471/1078-79?).

\section{(21) Delâilü'l-i'câz}

Ş̂râzî̉nin en çok etkisinde kaldığı eserlerden biri olan bu kaynaktan dokuz yerde yararlandığı görülmektedir. Eserin müellifini "el-İmâm Abdülkāhir", "eş-Şeyh Abdülkāhir” adlarıyla; eseri ise "Delâilüll-i'câz" adıyla zikretmektedir (vr. 5b, 10a, 12a, 15a, 19a, vd.).

\section{(22) Esrâru'l-belâğa}

Şîrâzî, iki yerde kaynak olarak kullandığı bu eseri, "Esrâru'l-belâğa" adıyla zikretmektedir (vr. 10a, 2ob).

Fahreddin er-Râzî: Ebû Abdillâh (Ebü’l-Fazl) Fahruddîn Muhammed b. Ömer b. Hüseyn er-Râzî (ö. $606 / 1210)$.

\section{(23) Nihâyetü'l-1̂câz fî dirâyeti'l-i'câz}

Şîâzî, bu eseri iki yerde kaynak olarak kullanmaktadır. Eserin müellifini "el-İmâm"; eseri ise "Nihâyetü'l-îcâz" adıyla zikretmektedir (vr. 5b, 12a).

Şirâzî, Delâilül'-i“câz'dan alıntı yaptığını belirttiği bazı yerlerde ibareyi Nihâyetül'lîcâz'da kısaltıldığı şekliyle aktarmaktadır (vr. 12a, 15a). Dolayısıyla ikinci el kaynak kullandığı halde birinci el kaynak kullanmış görüntüsü vermektedir.

Ziyâüddîn İbnü'l-Esîr: Ebü'l-Feth Ziyâüddîn Nasrullâh b. Muhammed b. Muhammed eş-Şeybânî elCezerî (ö. 637/1239). 


\section{(24) el-Meselü's-sâir fî edebi'l-kâtibi ve'ş-şâir}

Şîrâzî, bir yerde kaynak olarak kullandığı bu eserin müellifini “İbnü’l-Esîr”; eseri ise “el-Meselü’sSâir" adıyla zikretmektedir (vr. 10a).

Mu'izzî: Şemsüddîn Muhammed b. Fahriddîn Ebi’l-Kāsım b. Sâlih el-Hârizmî el-Mu'izzî (ö. 673/1274'ten sonra).

\section{(25) Nüshatü'l-Mu'izzî ( Miftâhu'l-‘ulûm)}

Şîrâzî, Miftâhu’l-‘ulûm'un müellif nüshasından nakledilen ve tashihli olan bu nüshayı on sekiz yerde kaynak olarak kullanmaktadır. Bu nüshanın sahibini "el-Mu'izzî", "el-Fâdıl el-Mu'izẑ”; nüshayı ise "Nüshatü'r-rivâye” adıyla zikretmektedir (vr. 14a, 14b, 26a, 27b, 31a, vd.).

\section{Edebiyat, şiir ve şiir şerhleri ile ilgili kitaplar}

Câhiz: Ebû Osmân Amr b. Bahr b. Mahbûb el-Câhiz el-Kinânî (ö. 255/869).

\section{(26) Kitabu'l-hayevân}

Şîrâzî bir yerde kaynak olarak kullandığı bu eserin müellifini "el-Câhız" adıyla zikretmektedir. Eseri ise zikretmemektedir (vr. 21b).

Mufaddal ed-Dabbî: Ebü’l-Abbâs Mufaddal b. Muhammed b. Ya'lâ ed-Dabbî el-Kûfî (ö. 178/794 [?]).

\section{(27) el-Mufaddaliyyât: Kitâbü'l-İhtiyârât}

Şîrâzî, bu eseri iki yerde kaynak olarak kullanmaktadır. Eseri "el-Mufaddaliyyât" adıyla zikretmektedir. Müellifi ise zikretmemektedir (vr. 58b, 59b).

Ebû Temmâm: Ebû Temmâm Habîb b. Evs b. Hâris et-Tâî (ö. 231/846).

\section{(28) Dîvânü'l-hamâse}

Şîrâzî, bu eseri üç yerde kaynak olarak kullanmaktadır. Eseri "el-Hamâse" adıyla zikretmektedir. Müellifi ise zikretmemektedir (vr. 37a, 42a, 51b).

Ebû Bekr İbnü'l-Enbârî: Ebû Bekr Muhammed b. el-Kāsım b. Muhammed el-Enbârî (ö. 328/940). (29) Şerhu'l-Mufaddaliyyât:

Şîrâzî, bu eseri aynı varakta iki yerde kaynak olarak kullanmaktadır (vr. 59a). Ancak müellifi ve eseri zikretmemektedir. Dolayısıyla bu yerlerde kaynak belirtmeden bilgi aktarımı yapmıştır.

Ebû Alî el-Fârisî: Ebû Alî Hasen b. Ahmed b. Abdilgaffâr el-Fârisî (ö. 377/987).

\section{(30) Kitâbu'ş-şi'r: Şerhu'l-ebyâti'l-müşkileti'l-i'râb}

Şîrâzî, bu eseri bir yerde kaynak olarak kullanmaktadır (vr. 43a). Ancak müellifi ve eseri zikretmemektedir. Dolayısıyla bu yerlerde kaynak belirtmeden bilgi aktarımı yapmıştır.

Merzûkî: Ebû Alî Ahmed b. Muhammed b. el-Hasen el-Merzûkî (ö. 421/1030).

\section{(31) Şerhu Dîvâni'l-hamâse}

Şîrâzînin en çok etkisinde kaldığı eserlerden biri olan bu kaynaktan on üç yerde yararlandı̆̆ görülmektedir (vr. 32b, 33a, 34b, 35a, 35b, vd.). Ancak müellifi ve eseri zikretmemektedir. Dolayısıyla bu yerlerde kaynak belirtmeden bilgi aktarımı yapmıştır.

Ebü'l-‘Alâ el-Ma‘arrî: Ebü’l-‘Alâ Ahmed b. Abdillâh b. Süleymân el-Ma'arrî (ö. 449/1057). 


\section{(32) Saktu'z-zend}

Şîrâzî, bir yerde kaynak olarak kullandı̆̆ı bu eseri "es-Sakt" adıyla zikretmektedir. Eserin müellifini ise zikretmemektedir (vr. 38b).

Hatîb et-Tebrîzî: Ebû Zekeriyyâ Yahyâ b. Alî b. Muhammed el-Hatîb et-Tebrîzî (ö. 502/1109).

\section{(33) Şerhu İhtiyârâti'l-Mufaddal}

Şirâzî̀nin en çok etkisinde kaldığı eserlerden biri olan bu kaynaktan yedi yerde yararlandığı görülmektedir (vr. 58a, 58b, 59a, 59b). Ancak müellifi ve eseri zikretmemektedir. Dolayısıyla bu yerlerde kaynak belirtmeden bilgi aktarımı yapmıştır.

Şîrâzî, burada açıklanan müellifler dışında da kaynak belirtmeden, birçok ilim adamı ve şairin adını zikreder. Meselâ: "Ebü’l-Kāsım ed-Dîneverî" (vr. 2a), "Hümâmüddin et-Tebrîzî" (vr. 4a), "Ebû Zeyd elEnsârî" (vr. 45b, 59a), "el-Eş'ar er-Rukbân el-Esedî” (vr. 54b), "İbnü’r-Râvendî” (vr. 55b), "Abdullah b. Aneme” (vr. 56b), "Ebû Ca“fer et-Taberî" (vr. 58b), "Rabîa b. Makrûm” (vr. 58b), "el-Kümeyt el-Esedî" (vr. 58b), "Tarafe b. el-'Abd” (vr. 59a), "Ebû 'Amr b. el-'Alâ" (vr. 59a), "İbnü’l-A'râbî” (, vr. 59b) vs. Bazen de isim vermeden "eş-Şâ‘ir/eş-Şư’arâ" (45a, 59a, 62a, 64a) ifadesini kullanarak şiir nakleder.

Şîrâzî, bazı yerlerde isim vermeden ya bir kişinin ya da bir grubun görüşünü aktarır. Meselâ: "Ba'd/elBa‘d/Ba'duhum” (vr. 2b, 5b, 6b, 8a, 13a, vd.), "Ba‘du'n-nâs" (vr. 8a), "Ba'du'l-kāilîn" (vr. 22b), "Ba'du'lkudemâ" (vr. 41b), "Ba‘du'l-efâdıl” (vr. 3ob, 5ob), "Ba‘du emâsili'l-efâdıl” (vr. 28b, 30a), "Ba‘du a‘yâni'lefâdıl" (vr. 51a), "Efdalü’n-nâs" (vr. 19a), "el-Cumhûr" (vr. 8a, 13a, 22b, 26b), "el-Fudalâ" (vr. 62a), "el'Ulemâ" (vr. 4a, 5a), "Ehlü'l-lügât” (vr. 19a), "en-Nuhât/en-Nahviyyûn” (19a, 44a, 52b, 53a), "Ulemâu'lbedî" (vr. 12a), "Ulemâu'l-beyân” (vr. 65a), "Ashâbu'l-me‘ânî" (vr. 44a), "el-Fukahâ" (vr. 55b), "elUsûliyyûn" (vr. 9a, 19a), "el-Müfessirûn" (vr. 56b), "el-Hukemâ" (vr. 9a, 18a, 19b), "el-Mantıkıyyûn" (vr. 13a), “el-Mütekaddimûn” (vr. 5b), "el-Müteahhirûn” (vr. 5b, 86), "Meşâyihu'l-Mu’tezile” (vr. 45a) vb.

\subsection{Yazma nüshaları}

Kayıtlara göre kütüphanelerimizde Miftâhu'l-Miftâh'ın yirmiden fazla nüshası bulunmaktadır. Bu nüshaların tamamını görme imkânı bulduk. Aşağıda bu nüshaları, bazı özellikleriyle kütüphane bölümlerine göre alfabetik olarak kısa kısa tanıtacă̆ız:

\section{Amcazade Hüseyin-394, vr. 1b-265a}

Bez kapak. Nesih yazı. Metin kısmı kırmızı mürekkeple yazılmış. Kenarlarda çok az tashih var. vr. 33a41b arası kopuk olup başka birisi tarafından ta'lik yazı ile yazılmış. Müstensih: Ebûbekr b. Halîfe. İstinsah tarihi: 10 Receb 733 (27 Mart 1333). İstinsah yeri yok.

\section{Atıf Efendi, nr. 2372, vr. 1b-287b}

Ta‘lik yazı. Metin kısmı kırmızı mürekkeple yazılmış. Pek tashih yok. Kenarlarda bazı notlar var. Feră̆ kaydının peşinde Miftâhu'l-Miftâh'ın telif tarihi ile ilgili kayıt var. Müstensih: Hacı Teây b. Selûdi etTürkistânî. İstinsah tarihi: 30 Safer 726 (5 Şubat 1326). İstinsah yeri yok.

\section{Bağdatlı Vehbi-1775, vr. 1a-233a}

Bez kapak. Ta'lik yazı. Metin kısmı kırmızı mürekkeple yazılmış. Pek tashih yok. Baş tarafından iki veya üç varak eksik. Feră kaydının peşinde Miftâhu'l-Miftâh'ın telif tarihi ile ilgili kayıt var. Zahriyede 
kitabın adı Miftâhu'l-Miftâh şeklinde yazılmasına rağmen Ebû Muhammed el-Hüseyn b. Abdullah b. Muhammed et-Tîbî̀ye nisbet edilmiştir. Muhtemelen bu hata ilk varaklarda eserin ithaf edildiği kişi olan Muhammed et-Tîbî’nin isminin yer almasından kaynaklanmaktadır. Buradaki Muhammed et-Tîbî ise müellif değil de eserin ithaf edildiği kişidir. Ancak içerik olarak diğer nüshalarla karşılaştırdığımızda Kutbüddîn-i Şîrâzîye ait olduğundan emin olduk. Müstensih: Abdülazîz b. Muhammed b. el-Hüseyn b. el-Hümâm. İstinsah tarihi: 10 Safer 733 (31 Ekim 1332). İstinsah yeri yok.

\section{Beşir Ağa (Eyüp)-169, vr.1b-356a}

Meşin kapak. Ta‘lik yazı. Metin kısmı kırmızı mürekkeple yazılmış. Kenarlarda tashih kayıtları ve yer yer ( مطلب )'lar var. Baş tarafında Miftâh'ın mukaddimesi (vikâye 2a-2b), son tarafında da Miftâh'ın hatimesi var (vr. 356b-36ob). Müellif nüshasından nakledildiği anlaşılmaktadır. Zahriyede bu nüshanın Şîrâzî tarafından önemli bir kimseye hediye etmek için istinsah ettirildiğine dair kendi el yazısıyla kayıt yer almaktadır. ${ }^{17}$ Ayrıca son varakın (vr. 356a) hamişinde Şî̂âînnin kendi el yazısıyla şu yazı yer almaktadır: "Bu kitabın hatimesini doğru ve yanlışını belirlemek için mütalaa ettim. Bu, doğruya yakındır. Bu notu yazan Kutb eş-Şîrâzî'dir.”. ${ }^{18}$ Müstensih: Muhammed b. Muhammed b. Hasen el-Alevî. İstinsah tarihi: Receb 702 (Şubat-Mart 1303). İstinsah yeri: Şiraz.

\section{Beyazıd-6123, vr. 1b-265a}

Meşin kapak. Ta'lik yazı. Metin kısmı kırmızı mürekkeple yazılmış. Kenarlarda çok az tashih kayıtları ve yer yer ( مطلب )'lar var. Şiirler içerlek yapılmış. Müstensih: Ahmed b. Kāsım b. Alî b. Hüseyn. İstinsah tarihi: 3 Zilkade 979 (18 Mart 1572). İstinsah yeri yok.

\section{Carullah-1832, vr. 1b-261a}

Ta‘lik yazı. Metin kısmı kırmızı mürekkeple yazılmış. Kenarlarda tashih kayıtları, metni açıklayıcı notlar ve yer yer ( مطلب)'lar var. Zahriyede Miftâhu'l-Miftâh icâzeti var. ${ }^{19}$ Mukabele kaydı olan bir nüsha. Ferağ kaydında "Müellif nüshasından nakledilen bir nüshadan nakledilmiştir." diye kayıt var. ${ }^{20}$ Ancak vr. 19 ile 20 arasında, numaralandırma olarak gösterilmemiş olsa da, diğer nüshalarla karşlaş̧ırdığımızda içerik olarak 20-25 civarı varakın eksik olduğu görülmüsstür. Müstensih: İlyas b. Haydar. İstinsah tarihi: 2 Receb 745 (9 Kasım 1344) Salı günü büyük kuşluk vakti. İstinsah yeri: Dımaşk (Kılıcıyye Medresesi).

\section{Carullah-1833, vr. 1b-280a}

Ta'lik yazı. Metin kısmı kırmızı mürekkeple yazılmış. Pek tashih yok. Kenarlarda bazı notlar var. Şiirler içerlek yapılmış. Son tarafında önemli eksiklik var. Ferağ kaydı yok.

\footnotetext{
17 Bu nüshanın zahriyesinde şu not yer almaktadır:

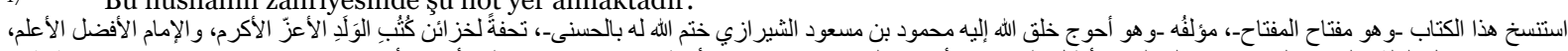

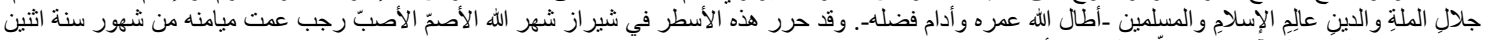

18 Bu nüshanın hatimesinde (vr. 356a) Şîrâzî, kendi el yazısıyla șu notu düşǚstür: وسبعمائة، حامدًا لله على آلائه، ومصلِيَّا على خاتم أنبيائه.

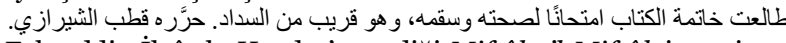

19 Bu nüshanın zahriyesinde Alî b. Mahmûd el-Konevînin Fahreddin İlyâs b. Haydar'a verdiği Miftâhu'l-Miftâh icazeti yer almaktadır. Bkz. Şîrâzî, Miftâhu'l-Miftâh, Süleymaniye Ktp., Carullah Blm., nr. 1832, zahriye.

20 Bu nüshanın zahriyesinde Alî b. Mahmûd el-Konevi’nin Fahreddin İlyâs b. Haydar'a verdiği Miftâhu'l-Miftâh icazeti yer almaktadır. Bkz. Şîrâzî, Miftâhu'l-Miftâh, Süleymaniye Ktp., Carullah Blm., nr. 1832, vr. 261 a.
} 


\section{Esad Efendi-3724, vr. 122b-126a}

Ta lik yazı. Birçok risaleden oluşan bir mecmuadır. Özellikle önemli bazı eserlerin mukaddimesi yer almaktadır. vr. 122b-126a arasında da Miftâhu'l-Miftâh'ın mukaddimesi yer almaktadır. Feră̆ kaydı yok.

\section{Fatih-4666, vr. 1b-177b}

Ta'lik yazı. Metin kısmı kırmızı mürekkeple yazılmış. Pek tashih yok. Kenarlarda bazı notlar var. Miftâhu'l-Miftâh'ın sadece ikinci cildinden oluşmaktadır. Feră̆ kaydının peşinde Miftâhu'l-Miftâh'ın telif tarihi ile ilgili kayıt var. Müstensih: Zeynü'l-Arab el-Mısrî. İstinsah tarihi: Evâsıt-ı (11-20) Receb 729 (28 Ağustos-6 Eylül 1319). İstinsah yeri yok.

\section{Fazıl Ahmed Paşa-1443, 1b-vr. 222b}

Meşin kapak. Ta'lik yazı. Metin kısmı kırmızı mürekkeple yazılmış. Kenarlarda çok az tashih kayıtları ve notlar var. Son tarafında ferağ kaydından sonra müzekker ve müennesle ilgili bir risale var. Müstensih: İbrahim b. el-Hâc el-Karâverânî. İstinsah tarihi: 7 Şevvâl 790 (9 Ekim 1388). İstinsah yeri yok.

\section{Feyzullah Efendi-1842, vr. 1b-224b}

Meşin kapak. Ta'lik yazı. Metin kısmı kırmızı mürekkeple yazılmış. Kenarlarda çok fazla tashih kayıtları ve notlar var. Tahkike esas aldığımız nüshalar dışında birkaç yerde bu nüshayı da kullandık. Müstensih: Abdülkerim b. Muhammed Bey b. Muhsin Danişmend. İstinsah tarihi: 30 Safer 797 (25 Aralık 1394). İstinsah yeri yok.

\section{Feyzullah Efendi-1853, vr. 1b-274b}

Nesih yazı. Metin kısmı kırmızı mürekkeple yazılmış. Pek tashih yok. Kenarlarda bazı notlar var. Şerhin tamamı değil de meâninin sonuna kadar yazılmış. Feră̆ kaydı yok.

\section{Hacı Beşir Ağa-567, vr. 1b-29ob}

Nesih yazı. Metin kısmı kırmızı mürekkeple yazılmış. Kenarlarda tashih kayıtları, metni açıklayıcı notlar ve yer yer ( مطلب )'lar var. Muhtemelen zayi olup sonradan tamamlandığı için vr. 9a-18b arası kâğıt ve yazı farklı. Mukabele kaydı olması, tashih ve notlarıyla güzel işlenmiş bir nüsha olması nedeniyle önemlidir. Müstensih: Eyyûb b. Kutlubey b. Muhyî el-Hanefí. İstinsah tarihi: 28 Şaban 784 (6 Kasım 1382) Çarşamba günü öğle vakti. İstinsah yeri: Antep (Şarkiyye Medresesi).

\section{Hafid Efendi-376, vr. 1b-256b}

Ta‘lik yazı. Metin kısmı kırmızı mürekkeple yazılmış. Pek tashih yok. Kenarlarda bazı notlar var. Son tarafında yaklaşık iki varaklık hâtime kısmı eksik. Müstensih, ferağ kaydında kitabın çoğunluğunu babasının yazdığını, ancak vefatı nedeniyle tamamlayamadığı kısmı ise kendisinin tamamladığını belirtmektedir. Müstensih: İdrîs b. Muhammed b. İsrafîl b. el-Hâcî el-Barğlâvî (Barla Köyü) ve babası. İstinsah tarihi: Rebiulevvel 762 (Ocak-Şubat 1361). İstinsah yeri: Felekâbâd (Eğirdir). 


\section{Kastamonu-1545, vr. 1b-319a}

Ta lik yazı. Metin kısmı kırmızı mürekkeple yazılmış. Çok az tashih var. Kenarlarda bazı notlar var. Müstensih: Hızır b. Hâcı Osmân es-Serâlî. İstinsah tarihi: Cemâziyelevvel 735 (Aralık 1334-Ocak 1335). İstinsah yeri yok.

\section{Kılıç Ali Paşa-873, vr. 1b-422b}

Ta‘lik yazı. Metin kısmı kırmızı mürekkeple yazılmış. Tashih yok. Son varaklarda kırmızı kalemle yazılması için bırakılan bazı metinler yazılamamış ve yerleri boş kalmış. Ferağ kaydı yok.

\section{Selimiye-1757, vr. 1b-2oob}

Ta'lik yazı. Metin kısmı kırmızı mürekkeple yazılmış. Çok az tashih var. Kenarlarda bazı notlar var. Son tarafında yaklaşık iki varaklık hâtime kısmı eksik. Ferağ kaydı yok.

\section{Serez-2476, vr.1b-436a}

Ta'lik yazı. Metin kısmı kırmızı mürekkeple yazılmış. Tashih yok. Ferağ kaydından sonra Kutbüddîn-i Şîrâzî ve Miftâhu'l-Miftâh ile ilgili güzel bir şiir ve telif tarihi ile ilgili kayıt var. Müstensih: Alî b. Hasen b. Alî et-Tüsterî. İstinsah tarihi: 710 (1310). İstinsah yeri: Nîsâbûr.

\section{Süleymaniye-898, vr. 1b-236a}

Nesih yazı. Metin kısmı kırmızı mürekkeple yazılmış. Pek tashih yok. Ferağ kaydı yok.

\section{Süleymaniye-899, vr. 1b-248b}

Nesih yazı. Metin kısmı kırmızı mürekkeple yazılmış. Pek tashih yok. Kenarlarda bazı notlar var. Şiirler içerlek yapılmış. İstinsah tarihi: Ramazan 750 (Kasım-Aralık 1349). Müstensih adı ve istinsah yeri yok.

\section{1. Şehid Ali Paşa-2246, vr. 1b-31ob}

Meşin Kapak. Ta'lik yazı. Metin kısmı kırmızı mürekkeple yazılmış. Tashih yok. Son tarafından bir veya iki varak eksik. Ferağ kaydı yok.

\section{1. Şehid Ali Paşa-2247, vr. 1b-317a}

Ta'lik yazı. Metin kısmı kırmızı mürekkeple yazılmış. Çok az tashih var. Kenarlarda bazı notlar var. İstinsah tarihi: 14 Muharrem 754 (19 Şubat 1353). Müstensih adı ve istinsah yeri yok.

\section{Veliyüddin Efendi-2792, vr. 1b-310a}

Meşin kapak. Zahriyeden önceki vr.a'daki adı: “Hâş̧iyetü’l-Kadîm ale’l-Miftâh”. Ta'lik yazı. Metin kısmı kırmızı mürekkeple yazılmış. Pek tashih yok. Bazı yerlerde ( مطلب )'lar var. Ferağ kaydı yok. 


\section{Yeni Cami-1039, vr. 1b-25ob}

Nesih yazı. Metin kısmı kırmızı mürekkeple yazılmış. Pek tashih yok. Kenarlarda bazı notlar var. Müstensih: Ali Haydar b. Muhammed. İstinsah tarihi: 9 Rebiulevvel 731 (21 Aralık 1330). İstinsah yeri yok.

Burada zikredilen nüshalar dışında kütüphane kayıtlarında yurtdışında bazı nüshaların varlığından söz edilmektedir. ${ }^{21}$

İran Milli Ktp., nr. 2839 (1191)'da yer alan nüshanın Miftâhu'l-Miftâh'a ait en eski nüsha olduğu iddia edilmektedir. Zahriyeden önceki sayfada ve feră̆ kaydında kitabın istinsah tarihi 700 (1301-1302) olarak geçmektedir. Ancak daha önce açılladığımız üzere Miftâhu'l-Miftâh'ın telif tarihi bu tarihten sonradır. Ayrıca diğer nüshalarla karşılaştırıldığında içerik olarak Miftâhu'l-Miftâh'la uyumlu olmadığı aksine Celâlüddin el-Kazvînî’nin el-Îzâh adlı eserin olduğu anlaşılmaktadır.

Fransa Milli Ktp., nr. 6612'de yer alan bir nüshanın zahriyesinde ve zahriyeden bir önceki varakta bu eserin Miftâhu'l-Miftâh olduğu kaydı yer almaktadır. Ancak diğer nüshalarla karşılaştırıldığında bunun da içerik olarak Miftâhu'l-Miftâh olmadı̆̆ı anlaşılmaktadır.

\section{9. Şerh yöntemi}

Şîrâzî, Miftâhu'l-Miftâh adını verdiği bu şerhin mukaddimesinde, eserin yazılış sebeplerini ve aşamalarını anlatırken aynı zamanda şerh yöntemi ile ilgili de bilgi vermektedir. Bunları kendi ağzından şu şekilde maddeler halinde özetleyebiliriz:

1. Bu şerhi metinle iç içe (memzûc) bir şerh olarak planladım. Metinle şerhin karışmamasına özen gösterdim (vr. 5a).

2. Öncelikle bu kitaptaki edebî lafızlar ile beyitlerin müşkillerini çözmeyi, ibare ve manalarındaki fesâhat ile istiârelerindeki güzelliği ortaya çıkarmayı amaçladım (vr. 4b).

3. Şerh ederken orta yolu takip edip abartılı davranmadım (vr. 4b). İzah ederken çok titiz davrandım. Ne usandıracak kadar uzattım, ne de anlamı ihlal edecek kadar kısalttım. Bilakis tam kararında ve ölçülü bir şekilde verdim. (vr. 4b).

4. Miftâh'ın sadece lafızlarını çözmek, terkiplerini açıklamak, kalıplarını düzenlemek ile yetinmedim. Ayrıca kurallarını yerleştirmek, kilit noktalarını vurgulamak, kastettiği şeyleri tefsir etmek, faydalı bilgilerini artırmak, veciz olan yerlerini genişletmek, düğümlerini çözmek, mücmel olan kelimelerini mufassal hale getirmek için çok çaba sarf ettim (vr. 4b).

Şîrâzî’nin bu aktardığımız yöntemlerinin dışında bizim tespit edebildiğimiz başka yöntemleri daha vardır. Bunları başlıklar halinde zikredelim:

\footnotetext{
${ }_{21} \quad$ Miftâhu'l-Miftâh'ın Türkiye dışında bulunan nüshalardan bazıları şunlardır:

Medrese-i Sipehsalar ktp. (Tahran), nr. 2991, Melik ktp. (Tahran), nr. 1157 ve 1283, Merkez-i İhyâ ktp. (Kum), nr. 2065, Şüşterî ktp. (Necef), nr. 518 . 


\subsubsection{Kelimelerin ve terkiplerin izahı}

Metinler terkiplerden, terkipler de kelimelerden oluşmaktadır. Bir metni tam anlayabilmek için kelimeleri ve terkipleri doğru şekilde anlamlandırmak önemlidir. Bu nedenle Kutbüddîn-i Şîrâzî, şerhinde kelime ve terkipleri şu şekilde izah etmiştir:

1. Sekkâkî’nin, Miftâh'in metninde kullandığı cümlelerde ve şahit olarak getirdiği beyitlerde bazı garip kelimeler yer almaktadır. Bu garip kelimelerin lügavî açıklamalarını yapan Şîrâzî, sık sık lügat kitaplarından istifade etmiştir (vr. 17a, 23b, 24b, 25a, 30a, vd.). Çoğunlukla da kaynak göstermeden esSihâh'tan istifâde ettiği anlaşılmaktadır.

2. Garip kelimelerin anlaşılmasının diğer bir yolu da sarf ilminden istifade etmektir. Çünkü sarf ilmi, kelimenin aslını ve onda meydana gelen değişiklikleri ortaya koyarak kelimeleri doğru bir şekilde anlamlandırmaya yardımcı olur. Bu nedenle Şîrâzî, metinlerde ve beyitlerde yer alan bazı kelimeleri sarf açısından incelemiştir (vr. 10b, 17a, 19a, vd.).

3. Cümle içindeki bir kelimeyi doğru bir şekilde anlamlandırdıktan sonra yapılması gereken en önemli şey o kelimenin gramer yapısını bulmaktır. Diğer bir ifadeyle nahiv ilmine başvurmaktır. Bu yüzden Şîrâzînnin, sıklıkla bu yönteme başvurarak kelimelerin ve terkiplerin irabını yaptığı görülmektedir (vr. 1ob, 11a, 13b, vd.).

4. Şirâzî, "Bazı zor lafızlar bana kolaylaştı, bazı ifadelerdeki karışıklıklar yok oldu, hakikat örtüsü bana açıldı ve başkalarına kapalı olan yerler bana aşikâr oldu."(vr. 3a) diyerek şerh yazma nedenleri arasında Miftâh'ın ifadelerinde yer alan gizlilikleri ortaya çlkarmak olduğunu belirtmektedir. Bu nedenle Şîrâzî, soyut, mübhem ve mücmel lafızları okuyucunun kolayca anlayabileceği bir hale getirmiş ve konuyu örnekler vermek suretiyle izah etmiştir (vr. 15b, 16b, 17b, vd.).

\subsection{2. Öğretici/pedagojik üslup kullanımı}

Şîrâzî, konuları şerh ederken okuyucunun durumunu da dikkate alan bazı üsluplar kullanır. Bunlardan bazıları şunlardır:

1. Şîrâzî, yeni bir konuyu şerhe başlamadan önce o konu ile ilgili ön bilgilere özet (mücmel) olarak yer verir. Asıl konu geldiğinde ise ayrıntılı (mufassal) olarak anlatır. Böylece okuyucu, ön bilgilere sahip olduğu için konuyu daha rahat anlamış olur. Mesela Şîrâzî, Miftâh'ın metnini şerh etmeye başlamadan önce okuyucunun zihnini kitaba hazır hale getirebilmek ve kitabın daha rahat anlaşılmasını sağlamak için, belagat konularını girişte özetlemiştir (vr. 5a-9a).

Şîrâzî, bu yöntemin faydalarını şöyle açıklıyor: Bu yöntem; Öğrenci bilgisizce asıl konuya giriş yapmasın diye bir uyarı olur. Konuya teşvik eder. Öğrencide farkındalık oluşturduğu için konuyu öğrenme isteği meydana getirir. Amaçlanan bilgi, öğrenme isteğiyle beraber elde edilince kalıcı olur. Çünkü şöyle bir söz vardır: "Talepten sonra elde edilen şey, yorulmadan ulaşılan şeyden daha kıymetlidir." (vr. 5a).

Bu yöntemde Şîrâzî, konuyla ilgili ön bilgileri verirken إِ إعلمُ (vr. 5a, 9a, 14a, vd.); asıl konuya geçerken ise و وإذَا عَرَفْتَ ذللك (vr. 5b, 7a, 9a, vd.) ifadelerini kullanır.

2. Şîrâzî, metinde geçen kelime ve cümleleri izah ederken أَيْ kelimesini, daha geniş izah gerektiren hususları açıklarken يَعْنِ (vرَ (vرَاد/ألْمُرَاد (vr. 10b, 12b, 15a, 9a, 14a, vd.), غَرَض (vr. 19a, 24b) ve 
آلْمَعَْى (vr., 2b, 14a, 15a, vd.) ifadelerini kullanır. Kelimeleri izah ettikten sonra bazen وذلكَ لِانََّ 22a, 24b, vd.) diyerek cümlenin toplu manasını verir.

3. Rivayet farklılıklarını, sarfi ve nahve dair tahlilleri belirttikten sonra cümlenin yeniden kurgulanmasına تَقْدِير/آَكَقِْْير (vr. 13a, 13b, 14a, vd.), alıntı yaptı̆̆ı bir metni kendi yorumuyla aktarmaya

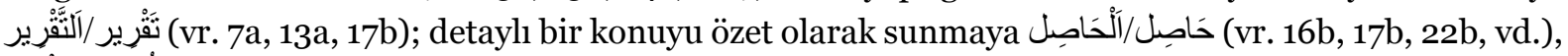
غَايَةُ مَا فِي الْبَابِ (vr. 8a, 57a) gibi ifadelerle başlar.

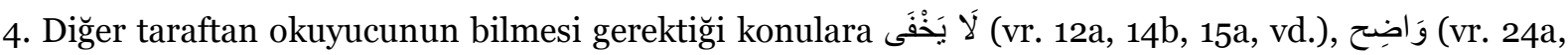

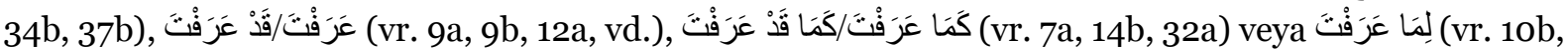
11a, 11b,) ifadeleriyle işaret eder.

5. Daha önce geçmemiş ya da üzerinde ittifak edilmemiş konularda kendi görüşlerini نَحَفْيق (vr. 8b, 11a,

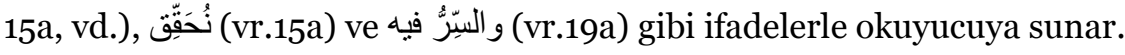

6. Anlattığ konuların delillerini ve gerekçelerini مَنْنَّ (vr. 18a) ve وَجْه (vr. 17a, 20a, 24b, vd.) gibi ifadelerle ortaya koyar.

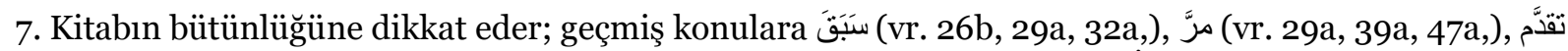

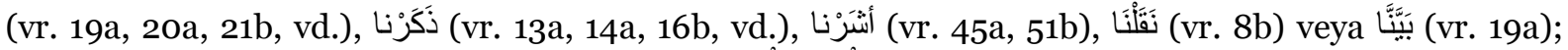

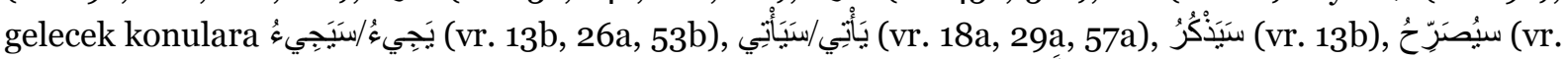

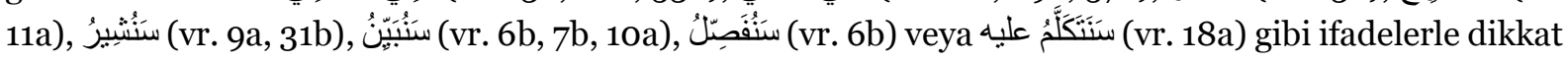
çeker.

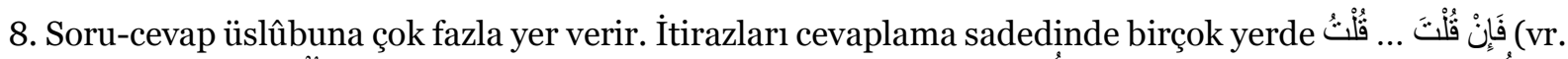

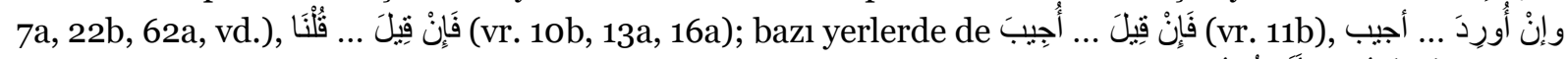

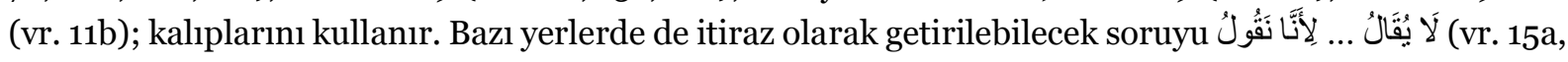
31a) diyerek kendisi sorar ve yanitlar.

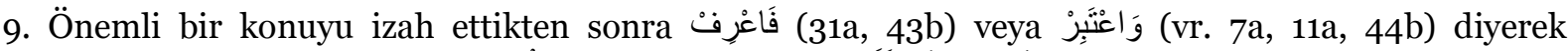

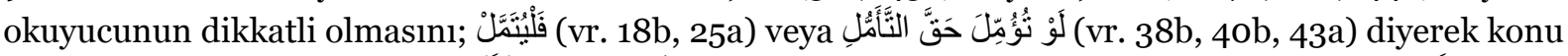

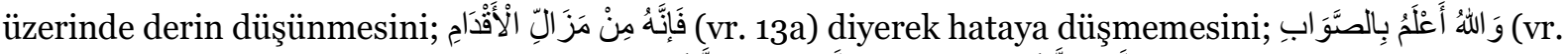

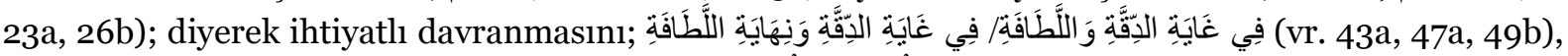

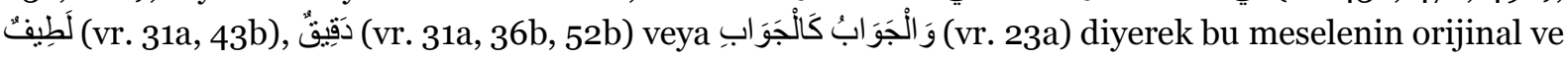
farklı olduğunu bilmesini ister.

\subsubsection{Delillerin (şevâhid) kullanımı ve izahı (istişhad yöntemi)}

Dil ilimlerinde bir konunun doğruluğunu isbat etmek amacıyla âyet, hadis, şiir ve mesel (atasözü/deyim) gibi delillerin kullanılmasına "istişhâd", bu delillere de "şevâhid" denir..22

Sekkâkî, Miftâh'ın metninde bolca şevâhid kullanmıştır. Şîrâzî de hem bunları şerhetmiş hem de kendisi ilave şevâhid kullanmıştır. Şîrâzînnin şevâhid ile ilgili yöntemi şu şekilde maddeleştirilebilir:

22 Ayrıntılı bilgi için bkz. Durmuş, 2001, XXIII, 396-397. 
1. Garip kelime ve kavramların izahını yapar (vr. 28a, 32b, 33a, vd.), sarf ve nahiv ilmine dair tahlillerde bulunur (vr. 27a, 29a, 30a, vd.). Bazen şevâhidde yer alan rivayet farklllıklarını (vr. 25b, 35a, 36b, vd.), bazen de edebî sanatları açıklar (vr. 33a, 36b, 37a, vd.).

2. Bazı yerlerde "söyleniş sebebi"ni zikreder. Yani âyet, hadis, şiir, mesel ve bazı ifadelerin niçin, ne zaman ve kim için söylendiğini belirtir (vr 28a, 33a, 42a, 50b, 59b, vd.).

3. Sekkâkî’nin eksik bıraktığı yerleri tamamlar (vr. 33a, 4ob). Bu yöntemi daha çok beyitleri izah ederken

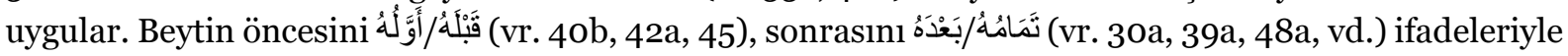
tamamlar.

4. Şevâhidin konu ile münasebetine değinir (vr. 27b, 28b, 29a, vd.).

5. Beyitleri izah ederken, bazen şiirin kime ait olduğunu belirtir (vr. 33b, 35a, 35b, vd.), bazen de şairin biyografisine yer verir (vr. 35a, 56b, 59a).

6. Kelimeleri izah ettikten sonra çoğu zaman آَلْعَنَى (vr. 27a, 33a, 33b, vd.) bazen de مُرَادُ الثََّّاعِِِ (vr. 32b, 42a) diyerek toplu mana verir.

7. Sekkâkî'nin kullandığı şevâhid dışında Şîrâzî, eserin incelediğimiz kısmında yetmiş altı ayet (vr. 12b, 14b, 20a, vd.), on bir hadis (vr. 27a, 3ob, 36a, vd.), otuz iki şiir (vr. 2a, 2b, 3a,) ve altı mesel (vr. 11b, 12a, 42b, vd.) kullanmıştır.

8. Sekkâkî, şevâhid kullanırken çoğu zaman istişhâdın bulunduğu yeri belirtmez. Şîrâzî, bu türden örneklerin geçtiği yerlerde istişhâd yerlerini belirtir (vr. 34b, 35b, 36b, vd.).

\subsubsection{Kaynaklardan bilgi aktarma yöntemi}

Şîâ̂zî, şerhinde birçok önemli kaynaktan bilgi aktarır. Bu kaynaklara yer verirken şu yöntemleri kullanır:

1. Bazen isim ve kaynak vererek bilgi aktarımı yapar. Bu yöntem için قَّ (vr. 2b, 5b, 7a, vd.), نقَّ (vr. 2b,

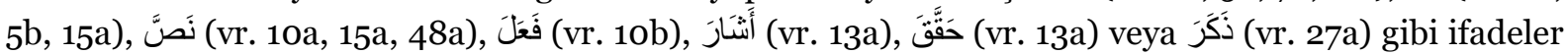
kullanır.

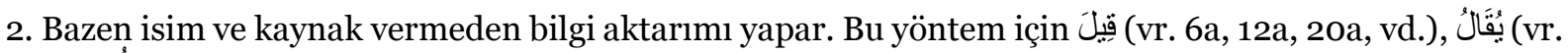
6a), يُوِْى (vr. 11b, 19b, 43a) veya gibi ifadeler kullanır.

3. Bazı kaynakları çok yoğun olarak kullanır. Örnek olarak lügat açıklamalarında Cevherînnin Sihâh'ından (vr. 17a, 23b, 24b, vd.), beyitlerin yorumlarında Merzûkînin Şerhu'l-Hamâse'sinden (vr. 32b, 33a, 34b, vd.), ayetlerin tefsirinde Keşşâf tan (vr. 2b, 41a, 46b, vd.), çok fazla yararlanır.

4. Bazen başka kaynaktan alındığını ima edecek hiçbir ifade olmadan nakil yapar. Lügat açıklamalarında Cevherî’nin Sihâh'ını (vr. 31a, 31b, 33b, vd.), beyitlerin yorumlarında İbnü’l-Enbârînin Şerhu'lMufaddaliyyât'ını (vr. 59a), Merzûkî’nin Şerhu Dîvâni'l-hamâse'sini (vr. 32b, 33a, 34b, vd.) ve Hatîb et-Tebrîzî̀nin Şerhu İhtiyârâti'l-Mufaddal'ını (vr. 58a, 58b, 59a, vd.) müellif ve eser ismi vermeden kaynak olarak kullanır. 
5. Bazen beytin izahını tümüyle bir kaynaktan verir (vr. 32b, 33a, 34b, vd.).

6. Alıntılar çok uzun olduğunda kaynakta yer alan bilginin baştarafını verip إِلَى آَخِِِ (vr. 8a, 11b, 14b, vd.) ifadesi ile sonlandırır.

\subsubsection{Farklı görüşler ve bunların tenkidi}

Şîrâzî, konuya katkı sağlamak ya da bazı belagatçilerin hatalarını tashih etmek için farklı görüşlere yer verir. O, farklı görüşlere yer verirken şu yöntemlerden bazılarını kullanır:

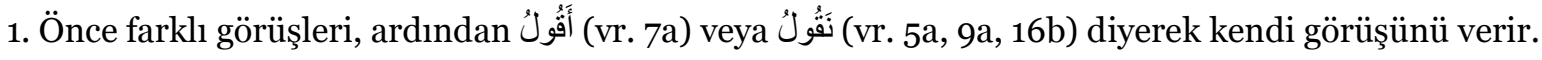

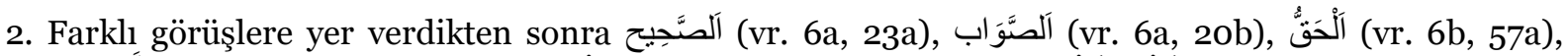

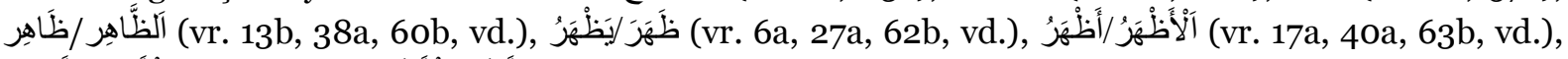

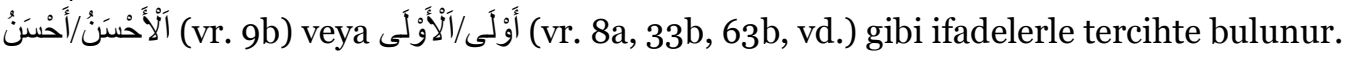

3. Sekkâkî’nin görüşlerini başkalarının görüşleri ile mukayese edip Sekkâkî’den yana tercihlerde bulunur (vr. 6a, 22b, 48a).

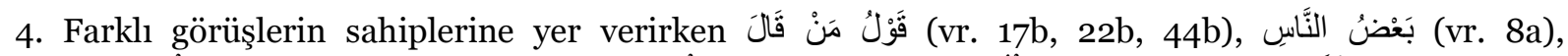

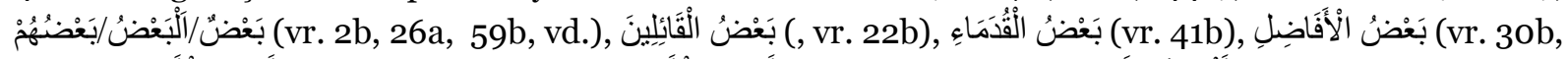

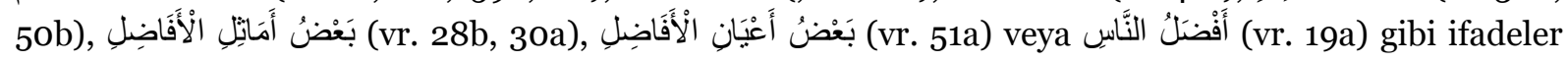
kullanir.

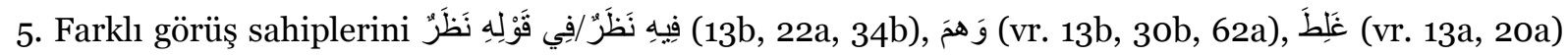
veya غَفَ (vr. 19a) gibi ifadeler ile eleştirir.

6. Bazı görüşleri aktardıktan sonra لَا طَائلِن نَحْتَهُ (vr. 11b, 44b, 62b, vd.) ifadesi ile o görüşün ilmî bir değeri olmadığını vurgular.

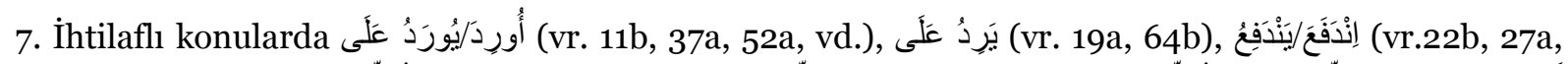

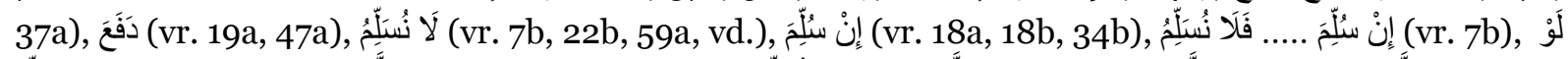

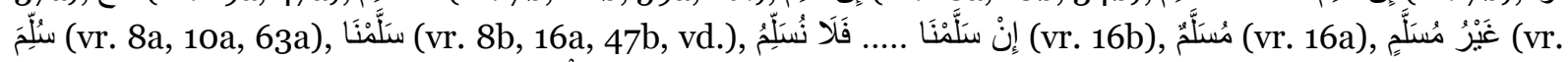

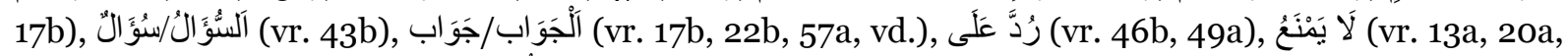

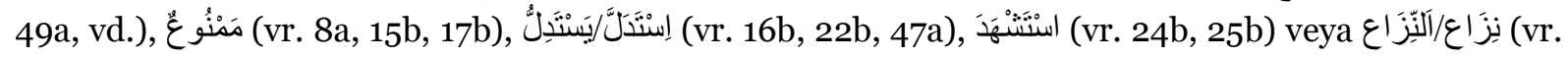
22b) gibi münâzara ilminin kavramlarını kullanır ve kaidelerini uygular.

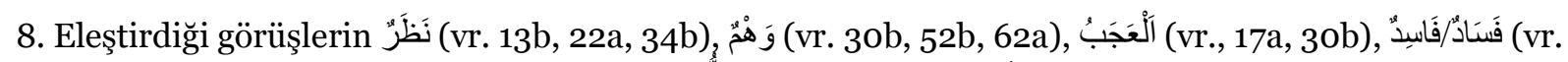

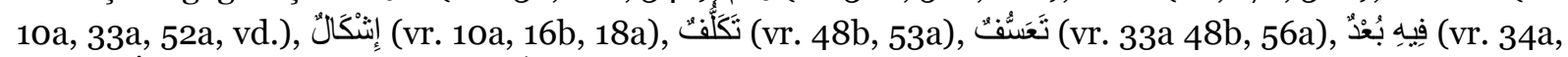

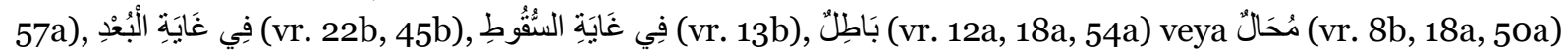
gibi kavramlar ile hata derecesine işaret eder.

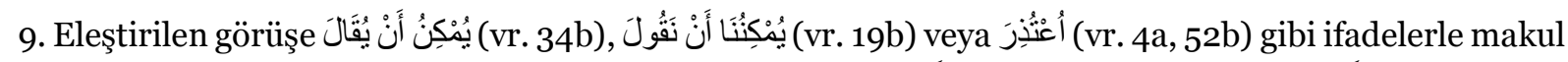

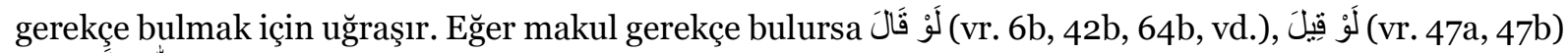

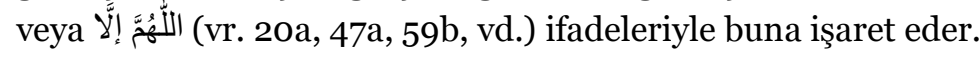




\subsubsection{Miftâh'ın farklı nüshalarına referans}

Şîrâzî, Miftâh'ın sağlam metnini bulmaya çalışır. Bunun için bazen nüsha farklılıklarını naklederek tercihte bulunur (vr. 13b, 17a, 28b, vd.). Bazen de bu nüsha farklılığının anlam üzerinde ne gibi etkisi olacağına vurgu yapar (vr. 13b, 20a, 24b, vd.).

Şîrâzî, en çok müellif nüshasından nakledilen ve tashihli olan Muizzînnin nüshasını "Nüshatü'r-rivâye" adıyla kaynak olarak kullanmaktadır (vr. 14a, 38a, 54b, vd.). Müellif nüshasından nakledilen bir başka nüshayı üç yerde "Nüshatün menkûletün mine'l-asl" (vr. 28b, 34b, 42a) ve müellifin tashih ettiği bir başka nüshayı ise dört yerde "nüshatün sahhahahâ el-Musannif/en-nüshatü’lletî sahhahahâ elMusannif” (vr. 52b, 57a, 62a) ifadeleriyle kullanmaktadır.

Diğer nüshaları ise altı yerde "kesirun mine’n-nüseh/ekseru'n-nüsah” (vr. 33a, 48a, 54b, vd.) birçok yerde ise "ba'zun-nüsah" (vr. 13b 16b, 2ob, vd.) ifadeleriyle kullanmaktadır.

\section{Sonuç}

Kutbüddîn-i Şîrâzî, aklî ilimlerde döneminin en güçlü isimlerinden biridir. Çünkü o, matematik, optik, coğrafya, fizik ve özellikle astronomi alanlarında yaptığı çalışmalarıyla ve ortaya koyduğu eserleriyle haklı bir şöhrete sahiptir. Diğer taraftan ilk dönemler ağırlıklı olarak felsefí ilimlerle meşgul olup eserler veren Şîrâzî, ömrünün sonlarına doğru dinî ilimlerde de yoğun çalışmalar yapmış ve bu alanda da kıymetli eserler kaleme almıştır.

Şîrâzî’nin eserlerinin önemli bir bölümü felsefî ilimler bir kısmı da dinî ilimler sahasında yer almaktadır. O, felsefî ilimlerden felsefe, matematik, astronomi ve tıp alanında, dinî ilimlerden tefsir, usûl-i fikıh ve belagat alanında çok kıymetli eserler kaleme almıştır. Bu ilim sahalarında yazılmış şerh, haşiye ve risaleleri olduğu gibi, müstakil kitap çalışmaları da bulunmaktadır. Şîrâzî, söz konusu eserlerini Arapça ve Farsça olarak telif etmiştir. Bu eserlerin büyük bir kısmı günümüze kadar ulaşmış olmakla birlikte, çok az sayıda eseri basılmıştır.

Şîrâzînnin bazı eserleri bilim ve düşünce tarihinde çok itibar görmüştür. Bunlardan Şerhu Hikmetü’lişrâk, Şerhu külliyyâti'l-Kānûn, Dürretü't-Tâc, Nihâyetü'l-idrâk, et-Tuhfetu'ş-Şâhiyye ve Mihtâhu'lMiftâh en çok önem atfedilen eserleridir.

Çalışmamızın konusu olan Mihtâhu'l-Miftâh, Abdülkāhir el-Cürcânî̀ye ait Delâilü̉l-î‘câz ve Esrâru'lbelâğa'dan sonra, belâgat alanında en önemli kabul edilen ve Sekkâkî̀ye ait olan Miftâhu'l-'ulûm'un ilk ve en önemli şerhlerinden biridir.

Bu şerhi detaylı bir incelemeden geçirdikten sonra şu sonuçlara ulaştık:

1. Şîrâzî bu şerhi ömrünün sonlarına doğru ilmi olgunluğa ulaştığı dönemlerde 701 (1302) yılında 67 yaşındayken tamamlamıştır.

2. Şîrâzî, bu eserini metin ve şerh iç içe (memzûc) tarzda yazmıştır.

3. Şîrâzî, mukaddimesinde eserin ismi, yazılış nedeni, süreci ve şerh yöntemi ile ilgili bizzat kendisi bilgi vermiştir. 
4. Şîrâzî, yöntem olarak konuları izah ederken önce o konuyla ilgili bir takım ön bilgilere yer vermektedir.

5. Şîrâzî, Miftâhu'l-'ulûm'un metninde soyut ve mücmel halde verilmiş konuları ayrıntılı bir şekilde açıklamış ve bir örnekle geçilmiş veya hiç örnek verilmeden değinilmiş meseleleri birden fazla örnek vermek suretiyle izah etme yoluna gitmiştir.

6. Şîrâzî, hem Miftâhu'l-'ulûm'un metninde yer alan şevâhidi şerhetmiş hem de bunların dişında kendisi de ilave şevâhid kullanmıştır.

7. Şirâzî, şerhinde meseleleri izah etmek ve konuyu zenginleştirmek için birçok önemli kaynaktan bilgi aktarmış ve önemli belâgatçilerin görüşlerine yer vermiştir.

8. Şîrâzî, Miftâhu'l-'ulûm'un metnini doğru tespit etmek için farklı nüshaların rivayetlerini naklederek değerlendirmeler yapmıştır.

9. Böyle önemli bir eserin tamamının tahkik edilip basılması özelde Miftâhu’l-ulûm'un anlaşılmasına, genelde ise belâgat ilminin öğrenilmesine önemli katkı sağlayacaktır.

10. Döneminin zirve isimlerinden biri olan Şîrâzînin yazma halinde bulunan tüm eserlerinin tahkik edilip basılması, medeniyet köklerimize ulaşmamız ve ilim geleneğimizi devam ettirmemiz hususunda çok önemli bir adım olacaktır.

Netice olarak böyle önemli bir eseri, belli bir bölümünü de olsa ilim dünyasına tanıtmaya gayret ettik. Çalışmamızın Şîrâzînin kütüphanelerimizde henüz yazma halinde bulunan tüm eserlerinin ilim dünyasına kazandırılmasına vesile olmasını ümit ederiz.

\section{Kaynakça}

Aksarâyî, Kerîmüddin (2000), Müsâmeretüll-ahbâr. Çev. Mürsel Öztürk. Ankara: TTK Yay.

Alak, Musa (2011a) Sekkâkî ve Miftâhu’l-'Ulûm Adlı Eseri, İstanbul: Sayfa Fotokopi \& Dijital Baskı.

Alak, Musa (2011b) Şeyhülislâm Molla Hüsrev'in Belâgatle İlgili Eserleri ve Hâşiye ale'l-Mutavveli”, İslâmî İlimler Dergisi, VI, Sayı 2, 95-134.

Birzâlî, Kâsım b. Muhammed (t.y.). el-Muktefí alâ Kitabi'r-Ravzateyn el-ma'rûf bi Târîhi'l-Birzâlî. Thk. Ömer Abdüsselâm et-Tedmûrî. Beyrut: el-Mektebetü'l-'Asriyye.

Cüneyd-i Şîrâzî (1344/1965). Şeddü'l-izâr fi haddi'l-evzâr an züvvâri'l-mezâr. Nşr. Mirzâ Muhammed Kazvinî, Abbâs İkbâl Âştiyânî. Tahran: İntişârât-ı Novîd.

Çelebi, Kâtib. (1941). Kesfü'z-zunûn an esâmi'l-kütübi ve'l-fünûn. Haz. Şerafettin Yaltkaya, Kilisli Rifat Bilge. Ankara: MEB Yay.

Durmuş, İsmail (2001).İstişhâd. DİA XXIII, 396-397. İstanbul: İSAM.

Eflâkî, Ahmed (1986). Menâkıbü’l-Ârifin (Ariflerin Menkıbeleri). Çev. Tahsin Yazıcı. İstanbul: Remzi Kitabevi.

Ertuğrul, Resul (2011). Kutbuddin eş-Şirazi ve Tefsiri, Doktora Tezi, Ankara: Ankara Üniversitesi SBE. İbn Hacer (1931). ed-Dürerü'l-kâmine fí a'yâni'l-mieti’s-sâmine. Beyrut.

İbnü'l-Fuvatî (1962). Telhîsu Mecma ‘’l-âdâb fî mu'cemi’l-elkāb. Thk. Mustafa Cevad, Dımaşk. 
Keleş, Mahmut Recep (2008). Kutbüddin Şîrâzî (1236-1311)'nin Hayat,, Eserleri ve Ortaçağ İslam Kültüründeki Yeri. Yüksek Lisans Tezi, İstanbul: Marmara Üniversitesi Türkiyat Araştırmaları Enstitüsü.

Mînovî, Müctebâ (1348/1969). Molla Kutb-i Şînâzî. Yâdnâme-i Îrâniyye Minorski. Haz. Müctebâ Mînovî, Îrec Efşâr, Tahran: Dânişgâh-1 Tahran. s. 165-205.

Meydan, Ahmet (2019), Kutbüddîn-i Şîrâzînin "Miftâhu'l-Miftâh" Adlı Eserinin Tahkik ve Tahlili (Baştan Müsnedün İleyh Bahsinin Sonuna Kadar). Doktora Tezi. İstanbul: İstanbul Üniversitesi Sosyal Bilimler Enstitüsü.

Razavî, Takî Müderris (1991). Ahvâl ve Âsâr-ı Hâce Nasîrüddîn-i Tûsî. Tahran: İntişârât-ı Esâmîr.

Safedî (1420/1999). el-Vâfi bi’l-Vefeyât. Thk. Ahmed el-Arnâûd, Türkî Mustafa. Beyrut: Dâru İhyâi'tTürâsi'l-'Arabî.

Sübkî, Tâcüddîn (1383/1964). Tabakātü'ş-Şâfiiyyeti'l-kübrâ. Thk. Abdulfettâh Muhammed el-Hulv, Mahmud Muhammed et-Tanâhî, Kahire: Matbaatu Îsâ el-Bâbî el-Halebî.

Şerbetçi, Azmi (2002). Kutbüddîn-i Şîrâzî, DİA, XXVI, 487-489. İstanbul: İSAM.

Şevkânî (t.y.). el-Bedrü't-tâli‘ bi mehâsini men ba‘de'l-karni’s-sâbi‘. Beyrut: Dâru'l-Marife.

Şîrâzî, Kutbüddîn. (nr. 3467). Şerhu’l-Kānûn, Nuruosmaniye Blm.

Şîrâzî, Kutbüddîn. (nr. 169). Miftâhu’l-Miftâh, Süleymaniye Ktp. Beşir Ağa (Eyüp) Blm.

Walbridge, John Tuthill (1983.) The Philosophy of Qutb al-Din Shirazi: a Study in the Integration of Islamic Philosophy, doctorate thesis, A thesis to The Departman of Near Eastern Languages and Civilisations, Boston: Harvard University.

Wiedemann, Eilhard (1977). Kutbeddîn. İA, İstanbul: MEB Yay. VI, 1049-1051.

Zehebî (1418/1998). Târîhu'l-İslâm ve vefeyâtü'l-meşâhîri ve’l-a lâm. Nşr. Ömer Abdüsselâm Tedmürî. Beyrut: Dâru'l-Kitâbi'l-'Arabî.

Zehebî (t.y.). Zeylü Târîhi'l-İslâm. Nşr. Mazen b. Sâlim Bâvezîr. Riyad: Dâru'l-Muğnî.

Ziriklî, Hayruddîn (1374/1955). el-A 'lâm Kāmûsu terâcim li-eşheri'r-ricâli ve’n-nisâi mine'l-'Arab ve’lmüsta'rabîn ve'l-müsteşrikîn. Kahire. 